\title{
Scope, phonology and morphology in an agglutinating language: Choguita Rarámuri (Tarahumara) variable suffix ordering
}

\author{
Gabriela Caballero
}

Received: 18 July 2008/Accepted: 21 December 2009/Published online: 8 April 2010

(C) The Author(s) 2010. This article is published with open access at Springerlink.com

\begin{abstract}
What is the nature of the interaction between scope, phonological conditions and morphologically specified precedence relations in determining affix combinatorics in morphologically complex languages? In depth studies of affix ordering patterns in typologically diverse languages reveal intricate interactions among multiple factors. Mixed scope/template systems, for instance, have been characterized as either involving scope taking precedence over templates [Athabaskan (Rice 2000)], or templates overriding scope [Chichewa (Hyman 2002, 2003) and Pulaar (Paster 2005)]. This paper makes an empirical contribution by documenting a novel type of affix order system of a previously unstudied language, Choguita Rarámuri, a Uto-Aztecan language spoken in Mexico, which features free affix permutation, and which cannot be characterized as either 'template-emergent' or 'scope-emergent'. In this agglutinating language, scope and morphological constraints are freely ranked, with phonological subcategorization overriding all other constraints. This paper also documents how semantically non-compositional suffix sequences may arise through priming effects and morphophonologically conditioned multiple exponence.
\end{abstract}

Keywords Scope Phonology - Variable affix order - Subcategorization · Uto-Aztecan · Tarahumara

\section{Introduction}

Are affix interactions a matter of arbitrary, language-specific constraints (a residue of diachrony) or are there synchronically active cross-linguistic principles governing

G. Caballero $(\square)$

University of California, San Diego, Department of Linguistics,

9500 Gilman Drive \#0108, La Jolla, CA 92093, USA

e-mail: gcaballero@ling.ucsd.edu 
these interactions? What is the status of semantic/syntactic scope (Baker 1985; Alsina 1999; Rice 2000), phonological conditions (Hargus and Tuttle 1997; Booij 2002; Paster 2006b) and language-specific morphological constraints (Hyman and Mchombo 1992; Inkelas 1993; Hyman 2003) in determining affix combinatorics in morphologically complex languages? In depth studies of particular language and language families and their affix order patterns reveal intricate interactions between, for instance, semantic compositionality and templatic restrictions: mixed scope/ template systems (Hyman 1993, 2003; Hyman and Mchombo 1992) have been characterized as either involving scope taking precedence over templates (Athabaskan; Rice 2000), or templatic constraints overriding scope [Chichewa (Hyman 2003) and Pulaar (Paster 2005)]. This paper makes an empirical contribution by documenting a novel type of affix order system of an endangered language, Choguita Rarámuri, which cannot be characterized as either 'template-emergent' or 'scope-emergent'. The affix order patterns of this language, which features free affix permutation, evidence a complex interplay between scope, phonological subcategorization and morphotactic constraints, where scope and morphotactic constraints are freely ranked, and where phonological subcategorization may override all other constraints. Finally, this paper, as part of a larger study focusing on this language's morphology and phonology (Caballero 2008), also documents how morphotactically stipulated suffix sequences may arise through priming effects and morphophonologically-conditioned multiple exponence.

In this agglutinating Uto-Aztecan language, there are three types of suffix permutations. First, there are forms where suffix ordering corresponds to semantic compositionality (scope; Baker 1985; Alsina 1999; Rice 2000), e.g. Desiderative and Causative: ${ }^{1}$
Stem
Gloss
Translation
a. /awi-nále-ri-/ 'dance-DESID-CAus' [X causes [Y want to dance] ]
b. /awí-ri-nale/ 'dance-CAUS-DESID' [X wants [cause $\mathrm{Y}$ to dance] ]

Second, there are forms where morpheme order is determined by phonological considerations, e.g. Desiderative and Evidential, where alternative suffix orders correlate with the prosodic properties of the base (Desiderative-Evidential with stress final bases (2a) and Evidential-Desiderative with pre-final stress bases (2b)):

\footnotetext{
1 Abbreviations used in this paper are: $1=$ first person; $2=$ second person; $3=$ third person; ACC $=$ accusative; $\mathrm{AFF}=$ affirmative; $\mathrm{APPL}=$ APPLICATIVE; CAUS $=$ causative; CAUS.I $=$ indirect causative; $\mathrm{CER}=$ certainty $\mathrm{CL}=$ final clitic; $\mathrm{COND}=$ conditional; $\mathrm{COP}=$ copula; $\mathrm{COMP}=$ complementizer; $\mathrm{DEM}=$ demonstrative; $\mathrm{DESID}=$ desiderative; $\mathrm{DUB}=$ dubitative; $\mathrm{EMPH}=$ emphatic; $\mathrm{EP}=$ epistemic; $\mathrm{EV}=$ evidential; FACT $=$ factitive; FUT $=$ future; GER $=$ gerund; $\mathrm{HAB}=$ habitual; $\mathrm{INCH}=$ inchoative; INT $=$ intensive; IRR $=$ irrealis; $\mathrm{IMP}=$ imperative; $\mathrm{MOT}=$ associated motion; $\mathrm{NOM}=$ nominative; $\mathrm{PASs}=$ passive; $\mathrm{PL}=$ plural; POSS $=$ possessive PROG $=$ progressive aspect; PST $=$ past; PTCP $=$ participle $; \mathrm{Q}=$ question particle; REL $=$ relative; $\mathrm{REV}=$ reversive; $\mathrm{SG}=$ singular; $\mathrm{TR}=$ transitive; $\mathrm{TAM}=$ tense $/$ aspect $/ \mathrm{mood} ; \mathrm{Sub}=$ subordination.
} 
(2)
Stem
Gloss
Translation
a. /wikará-na-čane/
'sing-DESID-EV'
[sounds like [X want to sing] ]
b. /atísi-ča-nale/
'sneeze-EV-DESID'
[sounds like [X want to sneeze] ]

Finally, there are words with variable suffix order, where suffix permutation is not driven by semantic compositionality or phonological subcategorization, e.g. Associated Motion and Causative in (3):
Stem
Gloss
Translation
a. /awí-ri-si-/ 'dance-CAus-mot-'
[X causes[Y to go along dancing]]
b. /sú-si-ti-/
'sew-MOT-CAUS-'
[X goes along causing [X to sew]]

Critically, pairs of suffixes displaying this type of non-compositional, variable ordering are also found with alternative orders corresponding to scopal interpretations.

This paper is structured as follows. In Sect. 2, I provide a general overview of the morphophonological properties of the Choguita Rarámuri verb, and give evidence showing that this morphological system is layered (i.e., not a position-class system), with a concentric structure of verbal domains or levels. In Sect. 3, I show how two of these verbal domains are composed of suffixes that can permutate their order. Permutations are driven by three conditioning factors: semantic compositionality or scope (Sect. 3.1), phonological subcategorization (Sect. 3.2), and morphotactic constraints (Sect. 3.3). In Sect. 4, I provide a formal analysis of the interplay between these three sources of affix order, and show how the system can be characterized as mixed scope/morphological (a kind of system similar to 'mixed scope/ template' systems, first described in Hyman 2003), where scope and morphotactic constraints are freely ranked. In Sect. 5, I present evidence showing that noncompositional suffix sequences may arise from priming effects (Sect. 5.1) and from morphophonologically motivated multiple exponence (Sect. 5.2). Finally, conclusions and questions for further research are given in Sect. 6.

\section{The Choguita Rarámuri verb}

Choguita Rarámuri verbal morphology is almost exclusively suffixing, highly agglutinating, ${ }^{2}$ with multiple valence-increasing markers (including three transitivizers, a causative and four applicatives) and a layered (i.e., non-templatic) structure with different degrees of morphophonological cohesion. There is semantic, morphotactic and phonological evidence for proposing twelve suffix positions that are grouped into six verbal zones or layers (Caballero 2008). From the inside-out, these are: an Inner Stem, the input to suffixation; a Derived Stem, with semantically restricted, unproductive derivational suffixes (Inchoative and Transitivizer suffixes);

\footnotetext{
${ }^{2}$ Defined generally through the criteria of separation/cumulation and invariance/variance. For a thorough discussion of further criteria and the attested types of mixture between agglutination and flexion, see Plank (1999).
} 
a Syntactic Stem, composed of valence-increasing suffixes (Causative and Applicative suffixes); an Aspectual Stem, with modality and aspectual suffixes (Desiderative, Associated Motion and Evidential); a Finite Verb level, with mood, voice, tense, and aspect suffixes; and an optional Subordinate Verb level, which adds deverbal morphology to verbal forms used in subordinate constructions. The degree of complexity of the system is schematized in (4).

(4) Categories expressed in the Choguita Rarámuri verb and verbal domains

\begin{tabular}{|c|c|c|c|c|c|c|c|c|c|c|c|c|}
\hline & $\begin{array}{ll}\text { S1 } \\
\end{array}$ & S2 & S3 & S4 & S5 & S6 & S7 & S8 & S9 & S10 & S11 & S12 \\
\hline & INCH & TR & $\begin{array}{l}\text { APP } \\
\text { L }\end{array}$ & CAUS & APPL & DESID & MOT & EV & $\begin{array}{l}\text { Voice/ } \\
\text { Aspect }\end{array}$ & TAM & TAM & SUB \\
\hline $\begin{array}{l}\text { Inner } \\
\text { Stem }\end{array}$ & $\begin{array}{l}\text { Derive } \\
\text { Stem }\end{array}$ & & $\begin{array}{l}\text { Synt } \\
\text { Stem }\end{array}$ & & & $\begin{array}{l}\text { Aspe } \\
\text { Stem }\end{array}$ & & & $\begin{array}{l}\text { Finite } \\
\text { Verb }\end{array}$ & & & $\begin{array}{l}\text { Sub } \\
\text { Verb }\end{array}$ \\
\hline
\end{tabular}

The forms in (5) exemplify the relative order of some of the categories expressed in the Choguita Rarámuri verb. Further evidence of this structure and the agglutinating character of this language is provided in Caballero (2008). ${ }^{3}$

$\mathrm{INCH}(\mathrm{S} 1)-\mathrm{TR}(\mathrm{S} 2)-\mathrm{APPL}(\mathrm{S} 5)-\mathrm{POT}(\mathrm{S} 9)$

a. /rata-bá-ča-ki-ra/

be.hot-INCH-TR-APPL-POT

'She/he may heat it up for somebody'

[BFL 08 1:21/el]

APPL(S5)-DESID(S6)-FUT.SG(S10)

b. /banisú-ki-na-ma/

pull-APPL-DESID-FUT.SG

'She/he will want to pull it for somebody'

[SFH 08 1:75/el]

TR(S2)-MPASS(S9)-PROG(S11)-SUB(S12)

c. /napa-bú-ri-a-či/

juntar-TR-MPASS-PROG-SUB

'When they would be gathered'

[SFH 06 in63(50)/in]

INCH(S1)-CAUS(S4)-MOT(S7)-PROG(S11)

d. /čukú-ba-ti-si-a/

stop-INCH-CAUS-MOT-PROG

'She is making him go along stopping (the truck)'

[BFL 08 1:90/el]

\footnotetext{
3 Transcriptions follow the Americanist tradition; /1/ represents a 'lateral flap', a segment that is articulated by making a ballistic contact with the tongue tip in the post-alveolar region, but the sides of the tongue allow air to flow laterally, resulting in a sound that auditorily resembles both a lateral approximant and an alveolar flap.
} 
The verbal structure depicted in (4) does not represent a slot-and-filler structure characteristic of position-class (templatic) morphologies as defined in Simpson and Withgott (1986) (see also Stump 2006). Choguita Rarámuri morphology instead exhibits several properties associated with layered systems.

First, in terms of the meanings of the categories expressed in the verb, the ordering of elements within the verbal structure conforms, at least in a general way, to proposed universal principles of cognitive relevance (Bybee 1985) and derivation within inflection (Bybee 1985; Greenberg 1963): denominalization and valencechanging markers (from the Inner Stem to the Syntactic Stem) are ordered before voice, mood and aspect/tense markers (clustered in the outer Finite Verb domain). ${ }^{4}$

Second, Choguita Rarámuri is consistent with Bybee's correlation of relevance with degree of phonological fusion (where inner (derivational) morphological exponents are expected to be more tightly fused phonologically with the root than outer (inflectional) ones (Bybee 1985, p. 97)). In the Choguita Rarámuri verb, phonological processes such as stress shifts (and stress dependent vowel reduction and syncope), root/suffix haplology, compensatory lengthening (CL) and rounding harmony, among other phonological phenomena, define a concentric structure, where morphological exponents closer to the stem display greater morphophonological fusion than outer morphological exponents. The scheme in (6) shows the domain of application of each phonological phenomenon within the verbal structure: haplology and compensatory lengthening apply only in the Inner Stem domain, while imperative stress shifts and vowel lengthening triggered by the past-passive marker apply to the Inner and Derived Stem levels; finally, round harmony applies to the Aspectual Stem and every other inner verbal domain.

(6) Morphologically conditioned phonology

\begin{tabular}{|l|l|l|l|l|l|l|l|l|l|l|l|l|}
\hline & S1 & S2 & S3 & S4 & S5 & S6 & S7 & S8 & S9 & S10 & S11 & S12 \\
\hline $\begin{array}{l}\text { Inner } \\
\text { Stem }\end{array}$ & $\begin{array}{l}\text { Derived } \\
\text { Stem }\end{array}$ & $\begin{array}{l}\text { Syntactic } \\
\text { Stem }\end{array}$ & $\begin{array}{l}\text { Aspectual } \\
\text { Stem }\end{array}$ & $\begin{array}{l}\text { Finite } \\
\text { Verb }\end{array}$ & & $\begin{array}{l}\text { Subordinate } \\
\text { Verb }\end{array}$ \\
\hline Haplology & &
\end{tabular}

An important phonological property in Choguita Rarámuri morphology is stress. The general properties of this language's stress system can be summarized as follows: (i) roots are underlyingly stressed or unstressed; (ii) suffixes are either 'stress-shifting' or 'stress-neutral' (occurring within vs. outside of the domain of

\footnotetext{
4 Applicatives within the Syntactic Stem occupy more than one position, since Applicative markers in an inner layer, formerly semantically distinct, have been lexicalized, and an outer Applicative marker is now the productive Applicative marker; there are processes which condition the simultaneous appearance of the inner lexicalized Applicatives and the outer, productive Applicative marker (Caballero 2008, to appear a, to appear b). As for the Finite Verb, phonological and morphotactic evidence shows that there are more than one position for tense/aspect/mood markers; these suffixes may co-occur and are semantically compatible (i.e., in contrast to position-class morphologies, it is not the case that semantically compatible affixes are blocked).
} 
stress assignment); (iii) stress is in either the verbal root or a stress-shifting suffix (if the root is unstressed); (iv) stress is never beyond the third syllable from left to right; (v) syllables are underlyingly coda-less and post-tonic syncope yields derived consonant clusters; and (vi) consonant clusters often demarcate a boundary between a base and any later, inflectional morphology of the finite verb. The distribution of stress-shifting and stress-neutral suffixes in the verbal structure is depicted in (7).

(7) Distribution of stress-shifting and stress-neutral suffixes in the verbal domains

\begin{tabular}{|c|c|c|c|c|c|c|c|c|c|c|c|c|}
\hline & S1 & $\mathrm{S} 2$ & S3 & S4 & S5 & S6 & S7 & S8 & S9 & $\mathrm{S} 10$ & S11 & S12 \\
\hline $\begin{array}{l}\text { Stem } \\
\text { level }\end{array}$ & \multicolumn{2}{|c|}{$\begin{array}{l}\text { Derived } \\
\text { Stem }\end{array}$} & \multicolumn{3}{|c|}{ Syntactic Stem } & \multicolumn{3}{|c|}{ Aspectual Stem } & \multicolumn{3}{|c|}{ Finite Verb } & $\begin{array}{l}\text { Sub } \\
\text { Verb }\end{array}$ \\
\hline $\begin{array}{l}\text { Stress } \\
\text { behavior } \\
\text { of suffixes }\end{array}$ & \multicolumn{2}{|c|}{ Shifting } & \multicolumn{3}{|c|}{ Neutral } & $\begin{array}{l}\text { Shif- } \\
\text { ting }\end{array}$ & \multicolumn{2}{|c|}{ Neutral } & \multicolumn{2}{|c|}{ Shifting } & $\begin{array}{l}\text { Neu- } \\
\text { tral }\end{array}$ & Neutral \\
\hline
\end{tabular}

The distribution of stress-shifting and stress-neutral suffixes within the verbal complex, though not neatly ordered in two blocks, also characterizes the different verbal domains (e.g., Derived Stem suffixes are stress-shifting, Syntactic Stem suffixes are stress-neutral, etc.).

In sum, the properties of the verbal structure that have been presented so far are not compatible with position-class systems (Simpson and Withgott 1986; Stump 1992; Inkelas 1993; Rice 2000; Good 2003). Position class systems are posited when affix order cannot be analyzed as driven by semantic/syntactic or even phonological structure, and when every morpheme in the system is assumed to be lexically indexed for a particular fixed position in a total linear arrangement of position classes. In this kind of system morphemes are rigidly ordered, there are formal dependencies between discontinuous suffixes, inflectional and derivational exponents are interspersed within the verbal structure, and semantically compatible suffixes might be in complementary distribution due to their membership to the same position class (Inkelas 1993). None of these properties, however, can be said to characterize the Choguita Rarámuri morphology. As we have seen, there is both semantic and morphophonological evidence for positing a layered structure in this language.

\section{Suffix permutation in Choguita Rarámuri verbal morphology}

\subsection{The data}

In the proposed verbal structure, suffixes belonging to two domains, the Syntactic and Aspectual Stem levels, can appear in alternative orders in a pair-wise fashion. The relevant suffixes, encoding valence-changing operations (Causative (CAUs) and Applicative (APPL)), modality (Desiderative (DESID) and Evidential (EV)) and aspect (Associated Motion (мот)), are highlighted in (8). 
(8) Variable suffix order in the Choguita Rarmuri verb

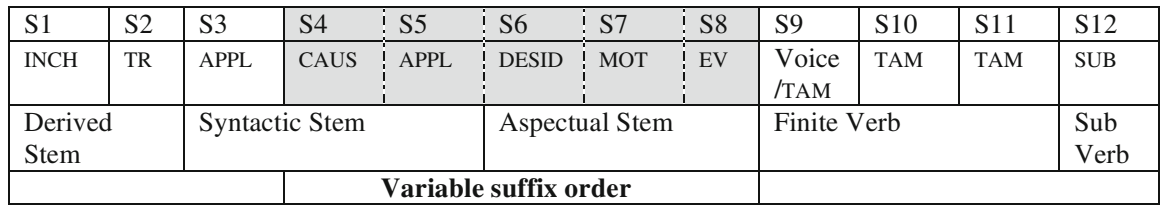

A list of the attested pair-wise suffix permutations in Choguita Rarámuri is provided in (9).

(9) a. Causative - $t i$ and Associated Motion -si;

b. Desiderative -nale and Associated Motion -si;

c. Causative - $t i$ and Desiderative -nale.

d. Desiderative -nale and Evidential -čane;

e. Causative - $t i$ and Applicative $-k i$.

Before addressing each of these interactions, I describe each of the suffixes involved in detail and the methodology with which the examples were obtained.

\subsubsection{The causative -ti suffix}

The causative suffix $-t i$ (S4) is a stress neutral suffix that introduces an agent (causer) argument to the argument structure of a predicate. Causativization applies to both intransitive and transitive verbs. In the causative construction exemplified in (10), the object corresponds to the subject of its basic, non-causative counterpart. ${ }^{5}$

a. Basic construction

$\begin{array}{lll}\text { ne } & \mathrm{mi} & \text { rimé-ni-ra } \\ \text { /ne } & \mathrm{mi} & \text { remé-ni-ra/ } \\ \text { 1SG.NOM } & \text { 2sG.ACC } & \text { make.tortillas-APPL-POT }\end{array}$

'I can make tortillas for you'

'Yo te hago tortillas'

[BFL 08 1:161/el]

b. Causative construction

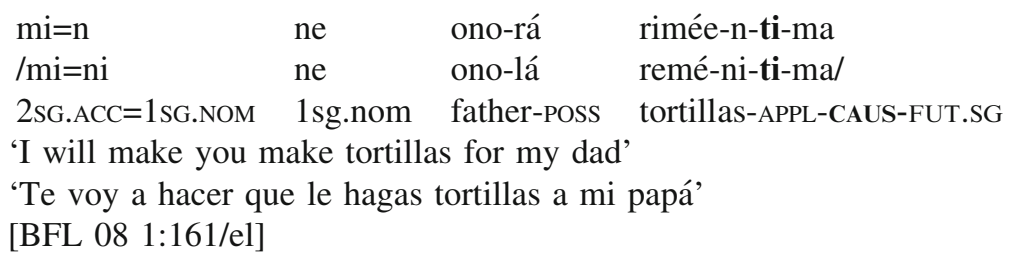

\footnotetext{
${ }^{5}$ Examples provided in this paper come from the author's fieldwork, and include source information that identifies consultant initials, date, document location and document type $(\mathrm{El}=$ Elicitation, $\mathrm{Tx}=\mathrm{Text})$. Treatment of examples include a Spanish translation, the language used during elicitation, in addition to the English translation. The data comes mainly from elicitation, and it should not be assumed that particular examples reflect speakers' personal lives or backgrounds, as many example forms come from constructed contexts. I am solely responsible for any potential misanalysis or erroneous translation.
} 
The Causative has two lexically determined allomorphs, -ti and -ri. The allomorphy is also partially phonologically determined, since there is a phonological process that devoices voiced/lenis consonants after another consonant (a derived environment stemming from stress-conditioned syncope). Examples of the distribution of allomorph $-t i$ are provided in (11).

(11) Phonological distribution of Causative allomorph - $t i$

$\begin{array}{lllll} & \text { Form } & \text { Gloss } & \text { Unattested } & \\ \text { a. láan-ti-ki } & \text { 'bleed-CAUS-PST.1' } & \text { *láan-ri-ki } & \text { [SFH } 05 \text { 1:102/el] } \\ \text { b. } & \text { sikirép-ti-ki } & \text { 'cut-CAUS-PST.1' } & \text { *sikirép-ri-ki } & \text { [BFL 05 1:113/el] } \\ \text { c. } & \text { o'péš-ti-a } & \text { 'vomit-CAUS-PROG' } & \text { *o'péš-ri-a } & \text { [BFL 05 1:136/el] }\end{array}$

The Causative $-t i$ suffix is extremely productive, displaying no restrictions as to the bases to which it can attach.

\subsubsection{The applicative -ki suffix}

The applicative suffix $-k i$ (S5) is another productive, stress-neutral suffix. This suffix introduces an additional argument to one-place or two-place predicates. The argument introduced is a benefactive or malefactive argument, ${ }^{6}$ i.e., the object can be favorably or adversely affected. In the applicative construction exemplified in (12b), the benefactive argument is an unmarked object, which would be expressed through a postpositional phrase in a non-applicative construction.

(12) a. Basic construction (two-place predicate)

nihé ba'arí sunú ori-méa
/nehé ba'arí
1sG.NOM tomorrow corn
'I will thresh corn tomorrow'
'Mañana voy a desgranar maiz'
[LEL 06 5:119/el]

b. Applicative construction (three-place predicate)

$\begin{array}{llll}\text { nihé } & \text { sunú orí-ki-ri } & \text { nehé } & \text { yé-ra } \\ \text { /nehé sunú orí-ki-li } & \text { nehé } & \text { yé-la/ } \\ \text { 1SG.NOM corn thresh-APPL-PST } & \text { 1sG.NOM mother-POSS } \\ \text { 'I threshed corn for my mom' } & & \\ \text { 'Le desgrané maiz a mi mamá' } & & \\ \text { [SFH 04 } & 1: 78 / \text { el] }\end{array}$

In (12a), the Applicative introduces a benefactive argument as an unmarked object (nehé yéra 'my mother') to a basic transitive predicate.

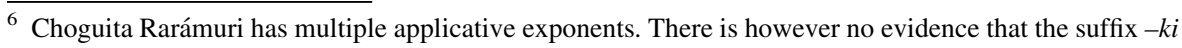
or any of the other Applicatives in Choguita Rarámuri introduce semantic roles other than the benefactive/malefactive. 


\subsubsection{The desiderative -nale suffix}

The disyllabic Desiderative suffix -nale is a stress-shifting suffix of agent-oriented modality. Derived from the verb naki 'want', it has the meaning ' $\mathrm{X}$ wants to/feels like doing $X$ ', where the 'wanter' and the subject of the desideratum predication are correferent (when these two arguments are not correferent, a periphrastic construction must be used). Examples from context are shown in (13).

$\begin{array}{llll}\text { a. ne biré niyúr-ka } & \text { sebá-nare } & \text { ba } \\ \text { /ne bilé niyúri-ka } & \text { sebá-nale } & \text { ba/ } \\ \text { INT one make.effort-GER } & \text { reach-DESID } & \text { CL } \\ \text { 'He really wanted to reach it' } & \\ \text { 'Lo quería alcanzar a fuerzas' } \\ \text { [BFL tr191(27)/tx] }\end{array}$
b. a'rí na mo'očíki čukú-ri-ri čapi-nár-a la'rí na mo'očíki čukú-ri-li čapi-nále-a/ and then headboard go.around-MOV-PST grab-DESID-PROG '.. and then he was going around near the (bed) headboard, wanting to grab him' 'Y entonces andaba por la cabecera queriéndolo agarrar' [LEL tx5(14)/tx]

Like the rest of the disyllabic suffixes in the language, the desiderative suffix has a 'short' monosyllabic allomorph (/-na/).

\subsubsection{The Associated Motion -simi suffix}

The Associated Motion suffix -simi (short allomorph /-si/) is a stress-neutral suffix derived from the free-standing motion verb simi ' $\mathrm{go}$ (sg.)'. This suffix is used when the event encoded by the verb is carried out while in motion (e.g., ' $\mathrm{X}$ goes along doing V'). Examples are provided in (14).

$\begin{array}{ll}\text { a. we } & \text { ko'á-simi } \\ \text { /we } & \text { ko'á-simi/ } \\ \text { INT } & \text { eat-MOT }\end{array}$

'They're going along eating'

'Van comiendo'

[SFH 08 1:71/el]

b. towí we nári-simi bu'učími

/towí we nári-simi bu'učími/

boy INT ask-MOT road

'The boy is going along the road asking a lot of things'

'El niño va preguntando muchas cosas por el camino'

[SFH 08 1:148/el] 


\subsubsection{The Evidential -čane suffix}

The Evidential $-\check{c}$ ane suffix (with short allomorph $-\check{c} a$ ) is a productive epistemic modality marker that indicates that the evidence of the proposition encoded by the predicate has an auditory (i.e. non-visual) source ('it sounds like $\mathrm{X}$ is taking place'). The (auditory) Evidential, which is stress-neutral, is exemplified in (15).

a. čéti torí ma toré-čane
/čéti torí ma toré-čane/
DEM.PL chicken already cackle-Ev
'It sounds like the chickens are already cackling'
'Ya se oyen cacarear las gallinas'
[SFH 08 1:160/el]
b. čoní-čane mačí
/čoní-čane mačí/
fight-EV outside
'It sounds/it seems like fighting is happening outside'
'Se oye/parece que pelean afuera'
[BFL 08 1:17/el]

\subsubsection{Methodology}

Examples of variable suffix ordering have been spontaneously produced and recorded during six years of field research with native speakers of Choguita Rarámuri. In order to test the nature of these permutations and assess the limits of the system (i.e., to determine with precision the meanings of each permutation and if all logically possible suffix combinations are attested), extensive elicitation with three adult speakers was carried out. While desirable to exclusively consider suffix permutation examples from a corpus where speech events had a lower degree of planning (such as monologues or conversations), such examples are rarely attested due to the highly specific semantic contexts they involve. Elicitation was thus critical in assessing the nature and limits of suffix permutations in this language. ${ }^{7}$

Speakers were given sentences in Spanish that would elicit pairs of suffixes, after a context was set up, either through text-based elicitation or a lengthy discussion of a possible scenario for each of the forms asked. Each consultant was asked, over several days and interspersed with other elicitation and transcription, for the translation of these sentences and discussion of their meanings. Discussion of the meanings of the forms provided included discussing contextual clues that would unambiguously indicate that a particular meaning was intended. This methodology

\footnotetext{
${ }^{7}$ It is important to note that this phenomenon is not, however, a byproduct of a particular kind of methodology or a marginal phenomenon in the language. Specifically, the suffix permutations discussed in this paper are not a one-time occurrence of an individual speaker after a long session of a particular type of elicitation; the permutations are recurrent and produced spontaneously by all consultants in different elicitation contexts.
} 
also enabled me to verify that speakers were consistent in the forms given for specific meanings and that none of the patterns documented would correlate with any idiolect.

This research program also included conducting elicitation using prompted forms in order to obtain grammaticality-judgment responses to different orderings offered. The offered forms were either constructed forms with logically possible affix orderings or forms produced by other speakers. I would ask speakers to assess the grammaticality of the offered forms and, if judged grammatical, to discuss their meanings in detail. I have avoided exemplifying any given pattern with this kind of evidence, and resort to all spontaneously produced data, except for cases where negative evidence (i.e., the ungrammaticality of a particular suffix sequence) is relevant in the discussion.

\subsection{Suffix order conditioning factors}

\subsubsection{Scope-determined suffix order}

An examination of the attested patterns of suffix order in Choguita Rarámuri reveals that most suffix sequences reflect semantic compositionality or scope. The role of scope as a driving force of affix order has been widely assumed in the theoretical literature. In the so called 'Mirror Principle', morphological derivations and syntactic derivations are assumed to be isomorphic (Baker 1985). The order of certain affixes in complex words is determined by the organization of the grammar, and not just by morphological or phonological factors alone. This generalization is summarized in (16):

(16) The Mirror Principle (Baker 1985, p. 375)

"Morphological derivations must directly reflect syntactic derivation (and vice versa)".

The Mirror Principle can be assumed to reflect lexical operations instead of syntactic derivations (Alsina 1999), but the core prediction remains the same: alternative orderings of morphemes will correlate with different meanings or semantic interpretations. Specifically, in scope-based affix permutations, we expect that when a suffix A has scope over suffix B, A is ordered outside B. Schematically: [[[V] B] A]].

The detailed analysis of morpheme order in Athabaskan languages led Rice (2000) to propose that the overarching mechanism constraining the linear arrangement of affixes in this language family is semantic scope. Her proposal, which I will refer to as the Scope Hypothesis, consists of three specific predictions. These predictions are given in (17).

(17) Scope Hypothesis (Rice 2000, p. 79)

a. Elements in a fixed scopal relationship occur in a fixed order with respect to each other;

b. Elements in which the scopal relationship can be reversed occur in variable order, with interpretation related to order; 
c. Elements that do not enter into a scopal relationship with each other may occur in different orders, both within a particular language and across the family.

These predictions, as we shall see next, are mostly borne out in the Choguita Rarámuri data.

First, let us consider the case of the relative order of Associated Motion and Desiderative. The examples in (18) show forms where the Desiderative has scope over the Associated Motion, and the order of these suffixes corresponds to their scopal interpretation. The underlying form of the relevant suffixes is indicated in the right-hand corner of each example's first (transcription) line.
[ [ [V] MOT] DESID]
[X wants to [go along V] ]
a. nihé ko
á ri'i-bú-s-nare
bu'učími
/nehé ko á
ri'i-bú-si-nale
bu'učími/
1SG.NOM EMPH AFF stone-remove-MOT-DESID road
'I want to go along the road removing stones'
'Quiero ir quitando piedras del camino'
[SFH 08 1:51/el]
b. tó-s-nare $=$ ni
/tó-si-nale $=$ ni/
take-MOT-DESID $=1 \mathrm{SG}$.NOM
'I want to go along taking them'
'Quiero írmelas llevando'
[BFL 06 5:149/el]
c. hesusíta=ni yúa ra'ičá-s-nare
/hesusíta=ni yúa ra'ičá-si-nale/
Jesusita=1sG.NOM with speak-MOT-DESID
'I want to go along talking with Jesusita'
'Quiero ir hablando con Jesusita'

[BFL 08 1:61/el]

d. éči ikí-s-nare birá=ti ba

léči ikí-si-nale belá=ti ba/

DEM happen-MOT-DESID really=1PL.NOM CL

'We want that to keep happening'

'Nosotros queremos que eso vaya pasando'

[BFL 08 1:87/el]

e. nihé ko wikokí á-si-nare

/nehé ko wikokí á-si-nale/

1SG.NOM EMPH mushrooms look.for-MOT-DESID

'I want to go along looking for mushrooms'

'Quiero ir buscando hongos'

[SFH 08 1:145/el]

In each of these examples, Desiderative takes scope over Associated Motion, and in each form the interpretation is that it is the event encoded by the verb, not the agent's desire, that will take place while in motion (e.g., 'go along taking', 'go along 
speaking'). This contrasts with the meanings of forms where Associated Motion takes scope over Desiderative. In these forms, it is the agent's wanting that takes place while in motion ('to go along wanting to do $X^{\prime}$ ). ${ }^{8}$ In (19) the order of Desiderative and Associated Motion suffixes corresponds to their scope.

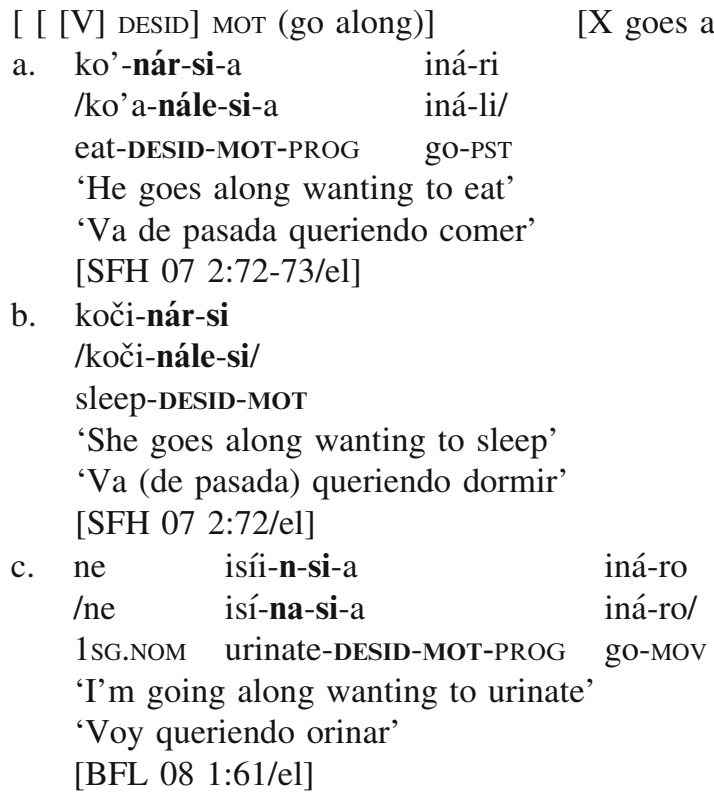

Another pair-wise suffix interaction that reflects scope is that between the Causative suffix and the Associated Motion suffix. In (20), the Associated Motion has scope over the Causative: the causative event is performed while in motion, and it usually implies that there are several events of causing. For instance, in (20c) there was an implication that one participant ('the girl') made repeated attempts at causing the other participant to become mad.

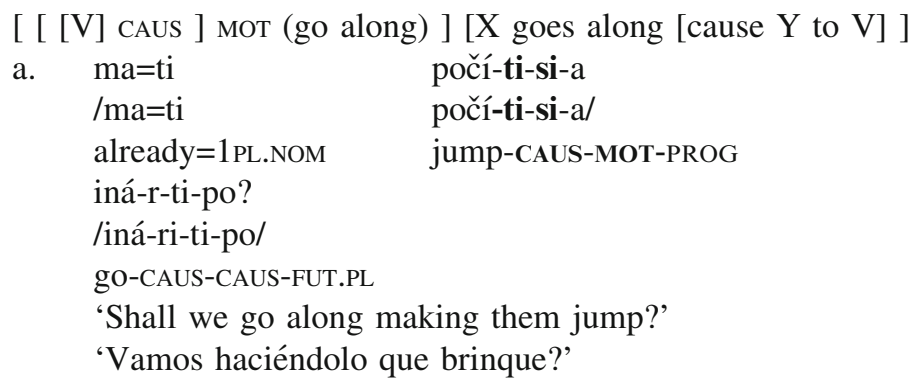

\footnotetext{
${ }^{8}$ Comparison of the verbal forms in (19c) (/isí-na-si-a/ 'urinate-DESID-MOT-PROG') and (19a-b) (/ko'anále-si-a/ 'eat-DESID-MOT-PROG', /koči-nále-si/ 'sleep-DESID-MOT') shows that this particular sequence (DESID-MOT) is not dependent on the stress properties of the root (i.e., both stressed roots (e.g., isí 'urinate' in (19c)) and unstressed roots (e.g., koči 'sleep' in (19b) may take the sequence DESID-MOT).
} 

b. ne mi bené-r-si-ma
/ne mi bené-ri-si-ma/
1SG.NOM 2SG.ACC learn-CAUS-MOT-FUT.SG
'I will go along teaching you (how to sing)'
'Yo te voy a ir enseñando (como cantar)'
[BFL 07 2:38/el]
c. na es tá tiwé tamí yó-r-si-a
/ne éči tá tewé tamí yó-ri-si-a/
this DEM DEM girl 1sG.ACC angry-CAUS-MOT-PROG
iná-ro
/iná-ro/
go-MOV
'This girl is going along making me mad'
'Esta niña va haciéndome enojar'
[BFL 08 1:91/el]
d. we tamí korú-ti-simi
/we tamí koru-ti-simi/
INT 1sG.ACC feel.like.eating-CAUS-MOT
'They are going along making me want to eat (eating in front of me)'
'Van haciéndome querer comer (comen enfrente de mi)'
[SFH 08 1:71/el]

In (21), by contrast, the opposite order of suffixes (Associated Motion followed by Causative) corresponds to the interpretation that the causing event takes scope over an event that takes place while in motion (e.g., 'to cause to go along singing' in (21a)). Crucially, discussion of these forms would involve clarifying that the causer did not engage in any motion (e.g., in (21a) the causer will not go on the road trip where the event will take place while in motion; the only event that can take place with associated motion under this interpretation is the one encoded by the lower predicate 'sing').

(21) [ [ [V] мот (go along)] CAus] [X causes [Y to go along V] ]

a. ma=ni mi wikará-s-ti-ma

/ma=ni mi wikará-si-ti-ma/

already=1sG.NOM 2sG.ACC sing-MOT-CAUS-FUT.SG

'I'll make you go along singing'

'Te voy a hacer que vayas cantando'

[BFL 07 2:32/el]

b. $\mathrm{mi}=\mathrm{n}$ tán-si-ti-ma orá

/mi=ni táni-si-ti-ma olá/

2SG.ACC=1sG.NOM ask-MOT-CAUS-FUT.SG CER

'I'll make you go along asking for things'

'Te voy a hacer que le vayas pidiendo'

[BFL 07 2:33/el] 


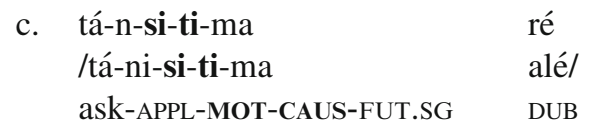

'She will make him go along asking them'

'Va a hacer que les vaya preguntando'

[SFH 08 1:72/el]

Finally, a third set of semantically compositional suffix permutations correspond to the Causative and Desiderative suffixes. In (22), each verb form contains a Desiderative-Causative sequence, where the causer makes the causee experience the desire to perform an event. Clarification of the intended meanings involved discussing a context in which the causee could be the only participant experiencing the wanting. For instance, the context of (22d) was a conversation about the speaker's young daughter, who would like to gently scratch the speaker's head, which would cause the speaker to become sleepy.

$$
\begin{aligned}
& \text { [ [ [V] DESID] CAUS] [X causes [Y to want V] ] } \\
& \text { a. mi=ni awi-nár-ti-ma orá } \\
& \text { /mi=ni awi-nále-ti-ma olá/ } \\
& 2 \text { SG.ACC }=1 \text { sG.NOM dance-DESID-CAUS-FUT.SG CER } \\
& \text { 'I will make you want to dance' } \\
& \text { 'Voy a hacer que quieras bailar' } \\
& \text { [BFL } 06 \text { 5:138/el] } \\
& \text { b. ba'wí bahí-n-ti-ri=ni } \\
& \text { /ba'wí bahí-na-ti-ri=ni/ } \\
& \text { water drink-DESID-CAUS-PST.PASS }=1 \mathrm{SG} . \mathrm{NOM} \\
& \text { 'They made me want to drink water' } \\
& \text { 'Me hicieron que quisiera tomar agua' } \\
& \text { [BFL } 06 \text { 2:43/el] }
\end{aligned}
$$

[BFL 08 1:63/el]

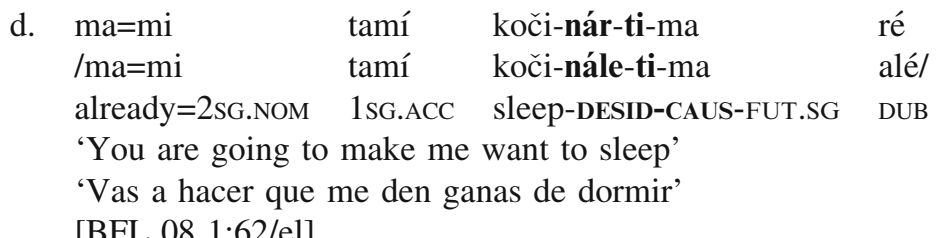

[BFL 08 1:62/el]

In (23), on the other hand, the Desiderative has scope over the Causative: the subject experiences the desire to make the causee perform the event encoded by the predicate. Morpheme order reflects this scopal interpretation. 


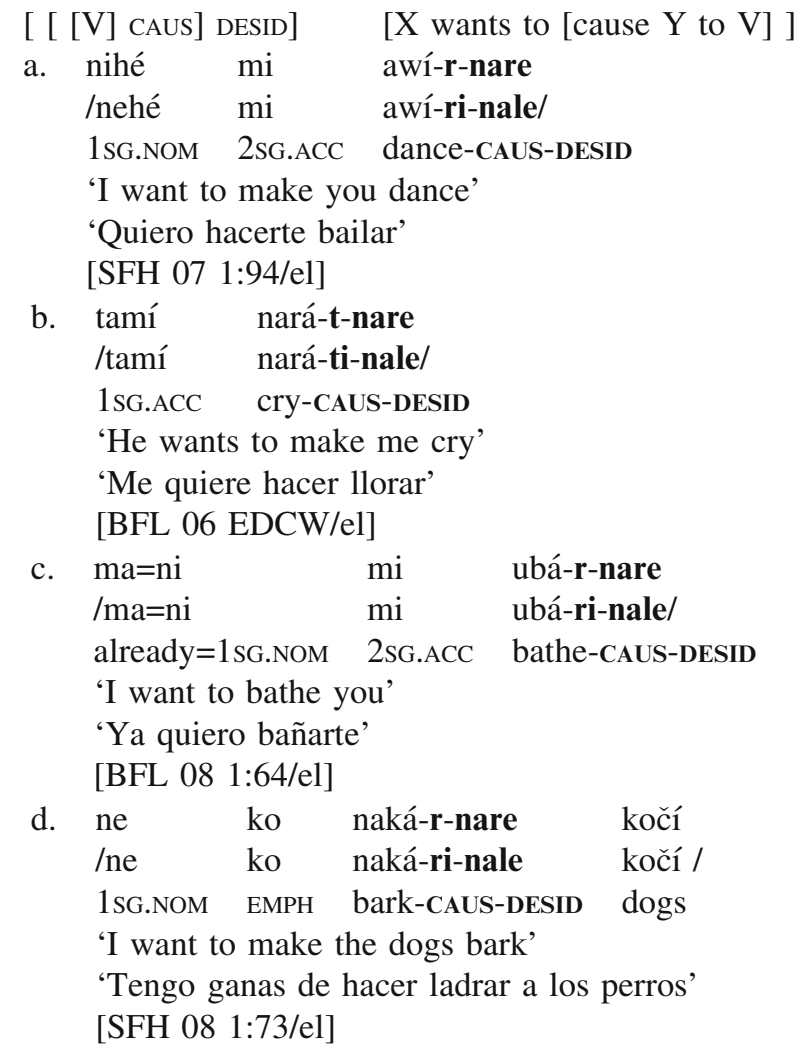

We thus have three types of suffix permutation patterns where suffix ordering reflects scope: that between Desiderative and Associated Motion, Causative and Associated Motion, and Desiderative and Causative. Scope, in addition, is also the predictor of unattested suffix permutations. These unattested permutations are summarized in (24).

(24) Unattested suffix sequences

a. The Evidential Suffix does not precede the Causative, Applicative or Associated Motion suffixes.

b. The Applicative does not follow the Desiderative, Associated Motion and Evidential suffixes.

Let us first consider the case of the Evidential suffix. I follow Rice (2000, p. 24) and take 'scope' to refer to semantic compositionality, where the semantics of a given element $Z$ has scope over $X$ and $Y$ if it is added to $X$ and $Y$ as a unit. $X$ and $Y$ will thus be in a closer semantic relationship to each other than with Z. In the case of the Evidential suffix and its interaction with Causative, Applicative, Desiderative and Associated Motion, the latter morphological operations will always be in a closer relationship to the base, as these operations modify the predicate, while the Evidential modifies the 
proposition that contains the predicate. I contend, thus, that this relationship is one of fixed scope. This relationship is schematized and exemplified in (25).

(25) Semantic interaction between Evidential and other operations

[it seems/sounds like [ V (CAUS, APPL, MOT, DESID)]

a. Causative-Evidential: It sounds like [X causes $\mathrm{Y}$ to do $\mathrm{V}]$

ubá-r-čane

/ubá-ri-čane/

'bathe-CAUS-EV'

'it sounds like $\mathrm{X}$ bathes Y'

[SFH 08 1:150/el]

b. Applicative-Evidential: It sounds like [X does $\mathrm{V}$ for $\mathrm{y}]$

tičí-k-čane

/tičí-ki-čane/

'comb-APPL-EV'

'it sounds like $\mathrm{X}$ combs $\mathrm{Y}$ for $\mathrm{Z}$ '

[SFH 08 1:128/el]

c. Motion-Evidential: It sounds like [X is going along doing $\mathrm{V}$ ]

wí-s-čane

/wí-si-čane/

'harvest-MOT-Ev'

'it sounds like $\mathrm{X}$ goes along harvesting'

[SFH 08 1:132/el]

d. Desiderative-Evidential: It sounds like [X wants to do $\mathrm{V}$ ]

čikó-n-čane

/čikó-na-čane/

'steal-DESID-EV'

'it sounds like $\mathrm{X}$ wants to steal'

[SFH 08 1:125/el]

Consistent with this semantic relationship, the order between these suffixes is fixed, with the exception of Desiderative and Evidential (the conditions determining this variable order are addressed in Sect. 3.2.2).

The second type of fixed suffix sequences involve the Applicative. With the exception of the Causative suffix, the Applicative precedes the other suffixes in the Aspectual and Syntactic Stems levels (the exceptional Causative-Applicative order will be addressed in Sect. 3.2.3). In each case, the Applicative has a closer semantic relationship with the base predicate than Causative, Associated Motion, Desiderative and Evidential. In terms of subset relationships, the Applicative has a more specific relationship with respect to the event encoded by the predicate than the rest of the morphological operations under consideration. Consider the following schematized meanings of hypothetical forms where Applicative would have greater scope than the other operations. 
(26) Hypothetical cases of Applicative scope relationships

a. CAUS and APPL: for the benefit of $\mathrm{Z}$ [X makes $\mathrm{Y}$ do $\mathrm{V}]$

where the causing event is done for the benefit of $\mathrm{Z}$

(vs. X makes $\mathrm{Y}$ [do $\mathrm{V}$ for Z])

b. MOT and APPL: for the benefit of $\mathrm{Z}$ [X goes along doing V]

where $\mathrm{Z}$ benefits from the event being performed while in motion

(vs. X goes along [doing $\mathrm{V}$ for $\mathrm{Z}]$ )

c. DESID and APPL: for the benefit of $\mathrm{Z}[\mathrm{X} \text { wants to do } \mathrm{V}]^{9}$

where the wanting benefits $\mathrm{Z}$

(vs. X wants [to do $\mathrm{V}$ for $\mathrm{Z}$ ])

d. EV and APPL: for the benefit of $\mathrm{Z}$ [it sounds like $\mathrm{V}$ is taking place] (vs. it sounds like [X does $\mathrm{V}$ for $\mathrm{Z}]$ )

I have already discussed the factors that suggest that the relationship between Evidential and other suffixes is one of fixed scope. With respect to the Applicative and the Evidential (e.g., (26d)), this is no exception. As for the rest of the hypothetical meaning relationships outlined in (26), it becomes apparent that a form where an Applicative would have greater scope over Causative, Associated Motion and Desiderative would entail a very particular relationship between the Applicative and a subconstituent of the embedded complex (specifically, the causing, associated motion or wanting), but not the whole complex. In contrast, every other morphological operation can modify an Applicative stem as a unit. Thus, we can also characterize this relationship as one of fixed scope. ${ }^{10}$ The Applicative is always more specific and within the scope of the rest of the suffixes. Consistent with this semantic relationship, there are no documented cases where the Applicative is ordered after the Desiderative, Associated Motion or the Evidential. Attempts of obtaining forms where morpheme order would correspond with the meanings schematized in (26) resulted in ineffability or the production of forms with related meanings which did not correspond to the target form.

In sum, scope is an important predictor of suffix interactions in Choguita Rarámuri: suffixes in a fixed order have fixed scope and suffixes appearing in variable order have reversed scopal relationships where order correlates with interpretation (see predictions of the Scope Hypothesis (17a-b)). However, not all suffix interactions stem from semantic scope, and other driving forces must be at play in determining attested suffix permutations in this language. It is to these patterns and driving forces that I turn next.

\footnotetext{
9 A form with an Applicative having scope over the Desiderative is, in addition, pragmatically odd, since it implies that an agent-oriented mental state would be conditioned by the effect of benefiting a second participant. The fixed scope prediction is that if an appropriate stimulus would be constructed that could overcome this pragmatic unnaturalness, we would still not be able to get a form where the Desiderative would be in the scope of the Applicative.

${ }^{10}$ As discussed in Sect. 3.2.3 below, there is evidence that the Causative $-t i$ is ordered before the Applicative - $k i$ without any semantic motivation. While the order between these two suffixes is opposite to their scopal relationship, recall from the schema presented in (4) that Choguita Rarámuri possesses three other Applicative exponents (in position (S3)). These suffixes are not productively used and must be lexically specified for which verbs they combine with morphologically. Their relationship with respect to the productive Causative $-t i$ suffix is consistent with their scopal relationship.
} 


\subsubsection{Phonologically conditioned suffix interaction}

Among the suffix interactions that do not stem from semantic compositionality in Choguita Raramuri is the relative order between the Desiderative suffix and the Evidential suffix. As discussed in Sect. 3.2.1, while the Desiderative modifies the predicate, the Auditory evidential modifies the proposition that contains the predicate. The semantic relationship between these suffixes can be schematized as follows.

(27) The interaction of Desiderative and Evidential

[it sounds like [X (wants) [V]]]

The Evidential will always modify the proposition, whether this proposition contains a predicate expressing agent-oriented modality or not. In (28), the order of these suffixes reflects their fixed scope.

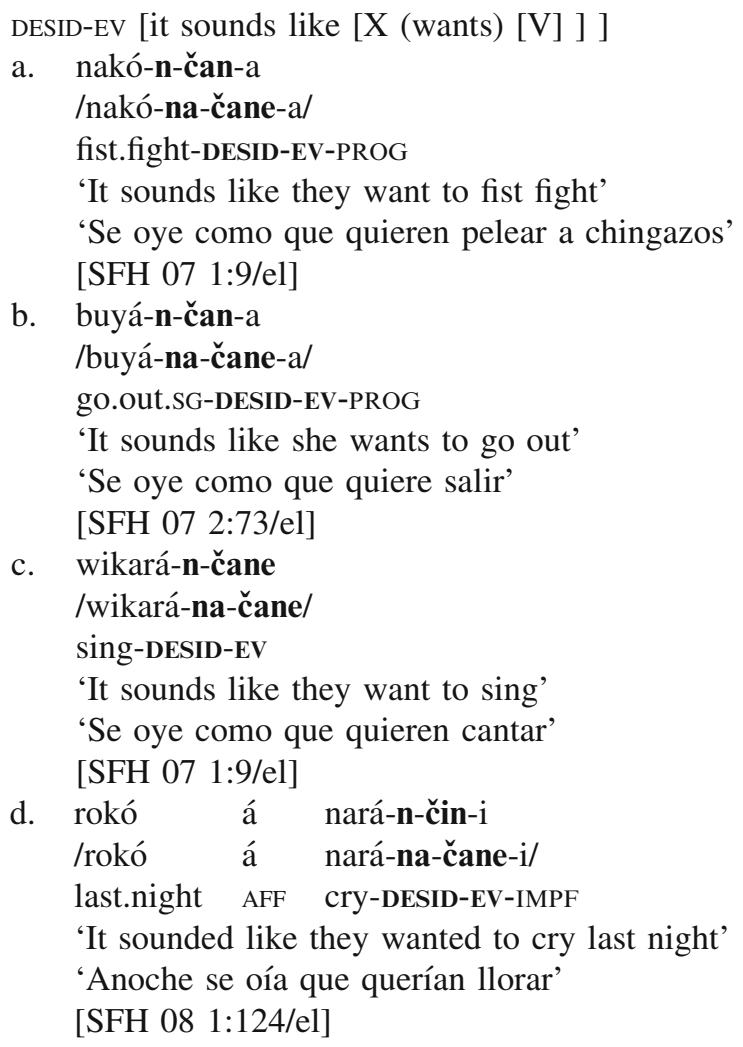

However, as the forms in (29) show, the Desiderative and Evidential suffixes can swap their order. The semantic interpretation, however, does not correlate with the order of the morphological exponents, since the meanings of (29) are the same as in (28) ("it sounds like X wants to V"). 
(29) EV-DESID [it sounds like [X (wants) [V] ] ]

a. atís-ča-nare

/atísi-ča-nale/

sneeze-EV-DESID

'It sounds like they want to sneeze'

'Se oye como que quieren estornudar'

[SFH 07 1:129/el]

b. opés-ča-nar-o

/opési-ča-nale-o/

vomit-EV-DESID-EP

'It sounds like they want to throw up'

'Se oye como que quieren vomitar'

[BFL 07 rec300/el]

c. paraér-ča-nar-o

/paraéri-ča-nale-o/

dance.paraéri-EV-DESID-EP

'It sounds like they want to dance paraéri'

'Se oye como que quieren bailar paraéri'

[BFL 07 1:182/el]

d. á birá čikle kéči-ča-nare kúruwi

lá birá čikle kéči-ča-nale kúruwi/

AFF really gum chew-EV-DESID kids

'It sounds like the kids want to chew gum'

'Se oye que los niños quieren mascar chicle'

[SFH 08 1:146/el]

The generalization that emerges from the distribution of each sequence is that the Evidential suffix attaches to pre-final stress bases, either a final stress root followed by another suffix (28) or a pre-final stress root with no intermediate suffix (29). ${ }^{11}$ After post-tonic vowel deletion applies, the surface generalization is that the Evidential attaches to a final stress base which is consonant final. ${ }^{12}$

The phonologically conditioned distribution of these suffix permutations falls in a straightforward fashion from an analysis where it is assumed that affix representations might include phonological requirements for stems to which they can attach

\footnotetext{
${ }^{11}$ That the correct generalization is made with respect to the underlying representation and stress properties of the base (pre-final stress base) and not its surface properties (consonant- vs. vowel-final base) is also shown by the following example:

i) nabisú-ča-nare /nabisúra-ča-nale/

form.line-EV-DESID

'It sounds like they want to get in line'

In this case, the evidential is ordered after a vowel-final base in the surface form. Underlyingly, however, the evidential attaches to a pre-final stress root that truncates a syllable.

12 This generalization does not apply in (29d), as alveopalatal affricate geminates [čč], the sequence that would result if post-tonic vowel deletion would apply, are not phonotactically permissible in this language.
} 
(Lieber 1980; Kiparsky 1982; Selkirk 1982; Inkelas 1990; Paster 2006a; Yu 2003, 2007). In this case, the Evidential suffix is sensitive to the phonological properties of the base to which it attaches, i.e., the Evidential subcategorizes for a foot to its left. This subcategorization requirement is schematized in (30).

(30) Choguita Rarámuri Evidential phonological subcategorization $\left[\left(\sigma \sigma_{F t}-\text { ča }(n e)\right]_{\text {Evidential }}\right.$

The role of phonological requirements within subcategorization frames in determining patterns of affix ordering have been shown to be necessary for Chintang, (Bickel et al. 2007). In this language, the distribution of variable positioning prefixes is captured through phonological subcategorization, as prefixes subcategorize for phonological words $(\sigma)$. The variability in prefix ordering in this language stems from the fact that words consist of several phonological words that can act as hosts for prefixes (e.g. a- $\left({ }_{\omega} \mathrm{kha}\right)\left({ }_{\omega}\right.$ tube $)$, 'you met us', vs. $\left({ }_{\omega} \mathrm{kha}\right)-\mathrm{a}\left({ }_{\omega} \mathrm{tube}\right)$ 'you met us') (Bickel et al. 2007, p. 22). In Choguita Rarámuri, the phonological pivot for affixation of the Evidential is consistent. This yields the attested Desiderative and Evidential ordering pattern.

\subsubsection{Morphotactically stipulated suffix interactions}

A third set of suffix interactions in Choguita Rarámuri are not driven by scope, phonological subcategorization or any other grammatical principle. One such case involves the interaction between the Causative $-t i$ suffix and the Applicative $-k i$ suffix. These suffixes can appear in an order that correlates with their scope: discussion of the meanings of these forms revealed that the intended meaning is that it is the event encoded by the predicate, and not the act of causing, that is performed for the benefit of a third participant. The ordering of the morphemes reflects this interpretation in (31).

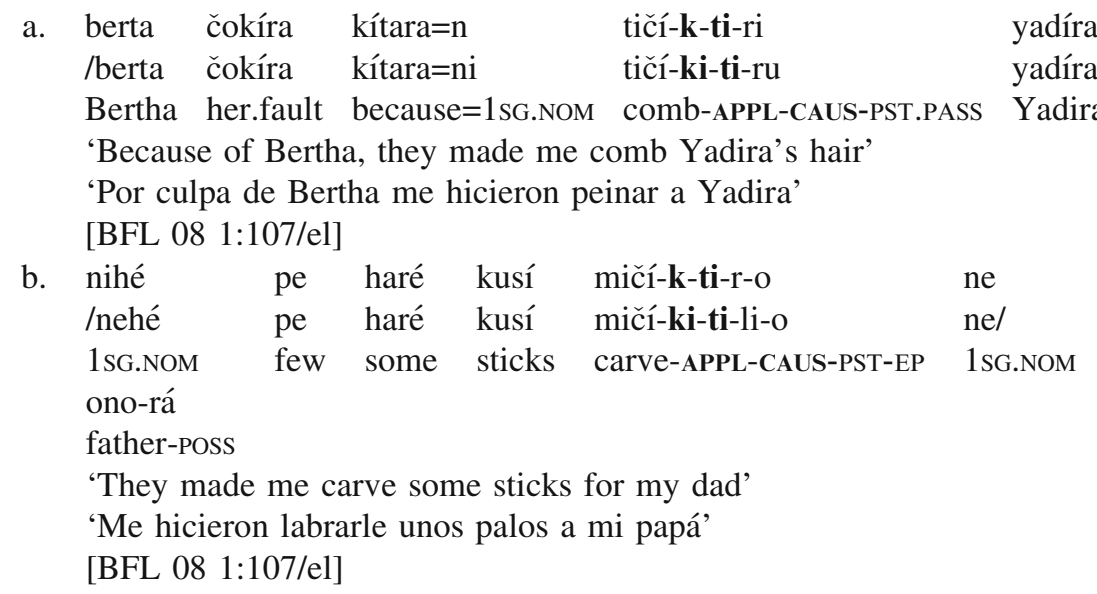


$\begin{array}{lllll}\text { c. to! } & \text { yéni } & \text { dúlse } & \text { íw-ki-ti-ri } & \text { yadíra } \\ \text { /to } & \text { yéni } & \text { dúlse } & \text { íwi-ki-ti-ri } & \text { yadíra/ } \\ \text { go! } & \text { Yeni } & \text { candy } & \text { bring.APPL-APPL-CAUS-IMP.SG } & \text { Yadira }\end{array}$

'Go! Make Jeni bring candy for Yadira'

'A ver, haz que Jeni le traiga dulces a Yadira'

[BFL 07 1:62/el]

These forms are compatible with scope, but the opposite order of suffixes does not entail a corresponding change in interpretation. The forms in (32), while displaying a Causative-Applicative order, are all interpreted with the Causative having scope over the Applicative. This suffix order is the most frequently attested in elicitation.
a. tamí $\mathrm{ko}=\mathrm{mi}$
/tamí ko=mi
o'pési-ti-ki-ma
1sG.ACC EMPH=2sG.NOM
vomit-CAUS-APPL-FUT SG
DUB CL
o’pés-ti-ki-ma
aré ba
alé ba/
'You'll make him throw up on me'
'Vas a hacer que me vomite encima'
[BFL 08 1:27/el]
b. tamí noké-r-ti-ki-ri
/tamí noké-ri-ti-ki-ri/
1sG.ACC move.APPL-CAUS-CAUS-APPL-IMP.SG
'Make him move it for me'
'Haz que me lo mueva'
[BFL 08 1:28/el]

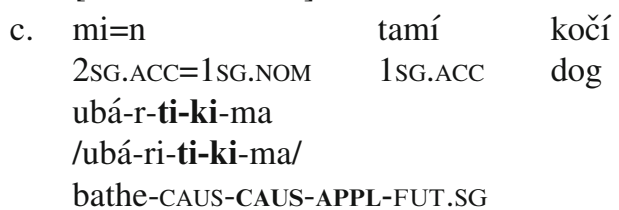
'I'll make you bathe the dog for me'
'Te voy a hacer que me bañes el perro'
[BFL 07 1:61/el]

There are in fact no forms with the Causative-Applicative sequence that are semantically compositional. Attempts at obtaining forms where Applicative would have scope over Causative ("for the benefit of Z, X causes Y to do V") would yield forms where the benefactive argument would be expressed through a postpositional phrase or forms with the opposite scope relationship. Speakers only accept one kind of interpretation, namely that of the Causative having scope over the Applicative (consistent with the proposal (in Sect. 3.2.1) that the Causative has fixed scope over the Applicative). The preferred order of Causative and Applicative cannot be understood to arise from any semantic or phonological principle, and must thus be morphotactically stipulated.

More strikingly, however, is the fact that Causative and Desiderative, Desiderative and Associated Motion and Causative and Associated Motion, pairs of suffixes shown in Sect. 3.1 to display scope-based permutations, are also found in linear arrangements that do not correspond to their semantic interpretation. Examples of non-compositional order between Causative and Desiderative are provided in (33). 
V-CAUS-DESID
a. nihé mi sú-r-ti-na-ma
/nehé mi sú-ri-ti-na-ma/
1sG.NOM 2SG.ACC Sew-CAUS-CAUS-DESID-FUT.SG
'I will make you want to sew'
'Voy a hacer que quieras coser'
[BFL 06 5:140/el]

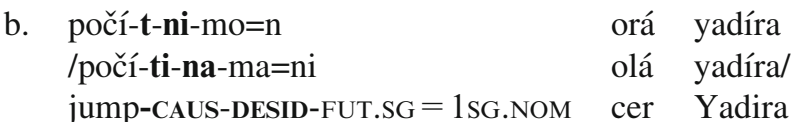
'I will want to make Yadira jump'
'Voy a querer hacer brincar a Yadira'
[BFL 08 1:62/el]
c. ti bimorí tamí rosowá-r-ti-nir-o
/ti bemorí tamí rosowá-ri-ti-nale-o/
DEM smoke 1sG.ACC cough-CAUS-CAUS-DESID-EP
'The smoke is making me want to cough'
'El humo me está haciendo querer toser'
[BFL 08 1:64/el]
d. ko'á-r-ti-ni-sa
/ko'á-ri-ti-na-sa/
eat-CAUS-CAUS-DESID-IMP
'Let's make her want to eat'
'Hay que hacerla querer comer'
[BFL 08 1:65/el]
e. pičí-r-ni-mo rá
/pičí-ri-na-ma olá/
sweep-CAUS-DESID-FUT.SG CER
'He will want to make him sweep'
'Va a querer hacerlo barrer'
[BFL 07 EDCW(81)/el]

Discussion of each one of the examples in (33) made it clear that speakers interpreted these forms with Causative having scope over Desiderative, i.e., with the meaning "X makes $\mathrm{Y}$ want to $\mathrm{V}$ ". Notably, there were no forms recorded where the opposite suffix order (V-Desiderative-Causative) would also be found with noncompositional semantics. This was not the case with Causative and Associated Motion, as both orders of this pair of suffixes were attested with a non-scopal interpretation. In $(34 \mathrm{a}-\mathrm{c})$, the meanings conveyed are roughly translated as " $\mathrm{X}$ makes Y go along doing V"), i.e., where Causative has scope over Associated Motion, but the Associated Motion morpheme is ordered after the Causative morpheme. In (34d) the opposite order of morphemes (V-Motion-Causative) does not correspond to the actual scopal relationship between these suffixes. The meaning for this sequence was unambiguously described as involving a causing event that took place while in motion. 
(34)

V-CAUS-MOT

$\begin{array}{llll}\text { a. } & \text { čémale ko } & \text { ne } & \text { kayápi } \\ \text { Chémale } & \text { EMPH } & \text { INT } & \text { frequently } \\ \text { čukú-b-ti-si-a } & & \text { iná-ri } & \text { martín } \\ \text { /čukú-ba-ti-si-a } & \text { iná-ro } & \text { martín/ } \\ \text { stop-INCH-CAUS-MOT-PROG } & \text { go-MOV } & \text { Martin }\end{array}$

'Chémale made Martin go along stopping (the truck)'

'Chémale hizo que Martín se fuera parando (en la troca)'

[BFL 08 1:90/el]

b. $\mathrm{mi}=\mathrm{n}$

piwá-r-si-mo

rá

$/ \mathrm{mi}=\mathrm{ni}$

piwá-ri-si-ma

olá/

2 SG.ACC $=1$ SG.NOM

smoke-CAUS-MOT-FUT.SG CER

'I'll make you go along smoking'

'Voy a hacer que vayas fumando'

[BFL 08 1:91/el]

c. rosária ko tamí awí-r-si-niri

/rosária ko tamí awí-ri-si-nale/

Rosaria EMPH 1SG.ACC dance-CAUS-MOT-DESID

'Rosaria wants to make me go along dancing'

'Rosaria quiere hacer que me vaya bailando'

[SFH 08 1:72/el]

$\mathrm{V}$-MOT-CAUS

d. nihé mi

/nehé mi

sú-s-ti-ma

sipúči

1SG.NOM 2SG.ACC

sú-si-ti-ma

sipúča/

'I will go along making you sew the skirt'

skirt

'Voy a ir haciendo que cosas la falda'

[SFH 08 1:121/el]

Finally, Desiderative and Associated Motion were also attested in forms where their linear arrangement did not correspond to their scope. In (35a-b), Associated Motion has scope over Desiderative ("X goes along wanting to do V"), but the linear order of these suffixes (with Desiderative ordered outside of Motion) is opposite to what we would expect if morpheme order would reflect scope. In (35c), the opposite scope between these suffixes (i.e., with Desiderative having wider scope (" $\mathrm{X}$ wants to go along $\mathrm{V}$ ")) is also found with the unexpected order (Motion ordered outside of Desiderative).

(35) Non-compositional order V-MOT-DESID
a. ne we ko'á-s-niri
/ne we ko'á-si-nale/
1SG.NOM INT eat-MOT-DESID
'I'm going along wanting to eat'
'Voy queriendo comer'
[SFH 08 1:71/el] 


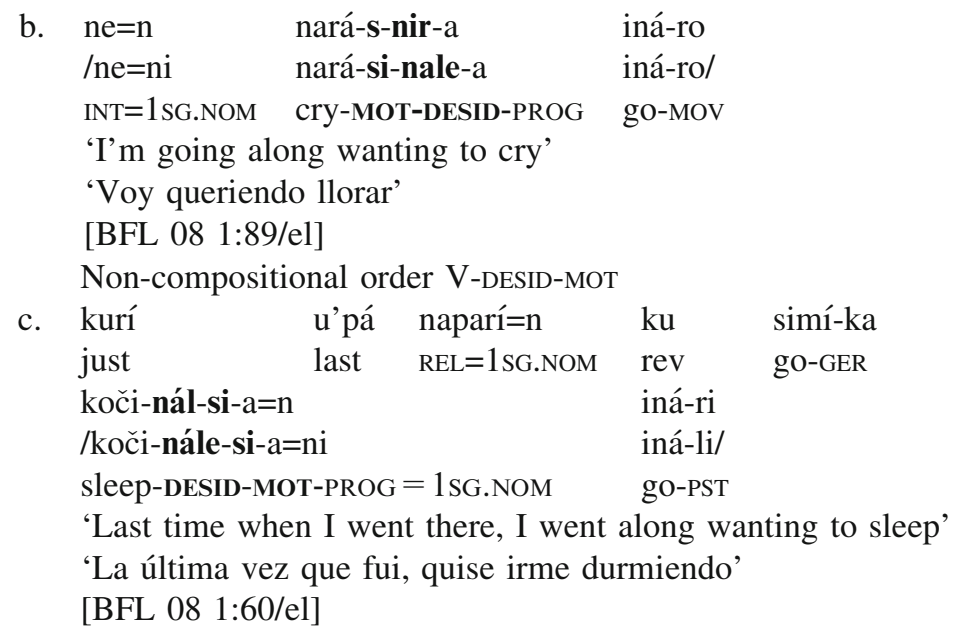

Thus, the same speakers that produce and identify verbal forms where there is a correlation between morpheme order and semantic compositionality also produce forms where the same suffix sequences cannot be reduced to any semantic principle.

Choguita Rarámuri patterns of morphotactically stipulated suffix order are summarized in (36).

(36) Choguita Rarámuri morphotactic suffix interactions

a. The Causative-Applicative order is either scopal or non-compositional (the opposite order (Applicative-Causative) is always compositional).

b. The Causative-Desiderative order is either scopal or non-compositional (the opposite order (Desiderative-Causative) is always compositional).

c. Any order between Associated Motion and Causative and between Desiderative and Associated Motion can be found with compositional and non-compositional semantics.

\subsection{Summary}

Attested and unattested permutations between Causative, Applicative, Desiderative, Associated Motion and Evidential in Choguita Rarámuri are summarized in Table 1. Each cell in this Table indicates whether each particular attested interaction is compositional ("comp.") or not. In the case of unattested sequences, each cell indicates if this gap is due to fixed scope. The cells representing double exponence of the same suffix are not considered. ${ }^{13}$

The generalizations of Choguita Rarámuri suffix permutations are summarized in (37).

\footnotetext{
${ }_{13}$ Cases of multiple exponence will be addressed in Sect. 5.2.
} 
Table 1 Attested and unattested suffix orders in syntactic and aspectual stem levels

\begin{tabular}{|c|c|c|c|c|c|}
\hline $\begin{array}{l}2^{\text {nd }} \rightarrow \\
1^{\text {st }} \downarrow\end{array}$ & CAUS & APPL & DESID & MOT & EV \\
\hline CAUS & & $\begin{array}{c}\checkmark \\
\text { non-comp. }\end{array}$ & $\begin{array}{c}\checkmark \\
\text { comp., } \\
\text { non-comp. }\end{array}$ & $\begin{array}{c}\checkmark \\
\text { comp., } \\
\text { non-comp. }\end{array}$ & $\begin{array}{c}\checkmark \\
\text { fixed scope }\end{array}$ \\
\hline APPL & $\begin{array}{c}\checkmark \\
\text { comp. }\end{array}$ & & $\begin{array}{c}\checkmark \\
\text { fixed scope }\end{array}$ & $\begin{array}{c}\checkmark \\
\text { fixed scope }\end{array}$ & $\begin{array}{c}\checkmark \\
\text { fixed scope }\end{array}$ \\
\hline DESID & $\begin{array}{c}\checkmark \\
\text { comp. }\end{array}$ & $\begin{array}{c}x \\
\text { fixed scope }\end{array}$ & & $\begin{array}{c}\checkmark \\
\text { comp., } \\
\text { non-comp. }\end{array}$ & $\begin{array}{c}\checkmark \\
\text { fixed scope }\end{array}$ \\
\hline MOT & $\begin{array}{c}\checkmark \\
\text { comp., } \\
\text { non-comp. }\end{array}$ & $\begin{array}{c}x \\
\text { fixed scope }\end{array}$ & $\begin{array}{c}\checkmark \\
\text { comp., } \\
\text { non-comp. }\end{array}$ & & $\begin{array}{c}\checkmark \\
\text { fixed scope }\end{array}$ \\
\hline EV & $\begin{array}{c}x \\
\text { fixed scope }\end{array}$ & $\begin{array}{c}x \\
\text { fixed scope }\end{array}$ & $\begin{array}{c}\checkmark \\
\text { non-comp. } \\
\text { phon-subcat }\end{array}$ & $\begin{array}{c}\boldsymbol{x} \\
\text { fixed scope }\end{array}$ & \\
\hline
\end{tabular}

(37) Choguita Rarámuri suffix permutations and their driving forces

a. Unattested permutations of Applicative and Evidential with other suffixes reflect their fixed scope.

b. The permutation of Desiderative and Evidential is conditioned by phonological subcategorization.

c. The ordering between Causative and Applicative is mostly non-compositional.

d. The ordering of Causative and Desiderative, Causative and Associated Motion and Desiderative and Associated Motion can either reflect scope or be non-compositional.

Next, I provide a formal account that models these generalizations.

\section{The interaction of phonological subcategorization, scope and morphotactic constraints in Choguita Rarámuri suffix order}

In order to account for the generalizations given above, Choguita Rarámutri affix order patterns can be analyzed as the result of the interaction between scope, phonological subcategorization and a series of language-specific morphologically specified precedence relations, formalized as violable constraints in an Optimality Theory analysis (OT; McCarthy and Prince 1993a,b; Prince and Smolensky 1993). In this system, scope and morphotactic constraints are freely ranked, since the same suffixes found with compositional semantics are also found in variable orderings 
that are not semantically or phonologically motivated. ${ }^{14}$ These constraints may be overriden by a phonological subcategorization requirement, stated as an alignment constraint.

As we have seen, many attested and unattested suffix permutations in Choguita Rarámuri fall from the Scope Hypothesis. I adopt Condoravdi and Kiparsky's Scope constraint, defined in (38).

(38) Scope constraint (Condoravdi and Kiparsky 1998)

SCOPE: Morphological constituency reflects scope

SCOPE interacts with morphotactic constraints, since there are suffix sequences in this language that can only be understood as being independent from any semantic, syntactic or phonological principle. This system is thus similar to the ScopeTemplate system proposed by Paster (2005) for Pulaar and Hyman's (2003) MirrorTemplate system proposed for Chichewa. ${ }^{15}$ I follow Paster (2005) and posit six local morphotactic constraints for Choguita Rarámuri that specify each pairwise interaction. These constraints are defined in (39).

(39) Choguita Rarámuri morphotactic constraints (MoRPHOLOGY)

a. $\quad \mathrm{C}>\mathrm{A}$ : Causative precedes Applicative

b. $\quad \mathrm{C}>\mathrm{D}$ : Causative precedes Desiderative

c. $\quad \mathrm{C}>\mathrm{M}$ : Causative precedes Associated Motion

d. $\quad \mathrm{M}>\mathrm{C}$ : Associated Motion precedes Causative

e. $\quad \mathrm{D}>\mathrm{M}$ : Desiderative precedes Associated Motion

f. $\quad \mathrm{M}>\mathrm{D}$ : Associated Motion precedes Desiderative

Recall from Sect. 3.2.3 that the orders Applicative-Causative and DesiderativeCausative are all compositional (i.e., there are no attested Applicative-Causative or Desiderative-Causative sequences with non-scopal interpretations). Hence, I do not posit constraints like $\mathrm{A}>\mathrm{C}$ or $\mathrm{D}>\mathrm{M}$. On the other hand, Causative and Associated Motion and Desiderative and Associated Motion can be found in any order with non-compositional semantics. I thus posit the constraints $\mathrm{C}>\mathrm{M}$ (cf. (34a-c)) and $\mathrm{M}>\mathrm{C}$ (cf. (34d)), as well as $\mathrm{M}>\mathrm{D}$ (cf. (35a-b)) and $\mathrm{D}>\mathrm{M}$ (cf. (35c)).

The tableaux in (40) and (41) show the need for ranking SCOPE above morphotactic constraints: both orders of Associated Motion and Desiderative (40) and Causative and Associated Motion (41) are attested. In each case, the order corresponds to semantic interpretation.

\footnotetext{
${ }_{14}$ For more references on free variation modeled through constraint free ranking, see Kiparsky (1993), Reynolds (1994), Anttila (1995), Guy (1997), Itô and Mester (1997), and Kager (1999).

15 In both of these systems, semantically motivated affix interactions co-exist with affix interactions that are purely morphological, whether the constraints to capture the former are articulated through a monolithic templatic statement (as in Hyman 2003) or through atomic, pair-wise constraints (as in Paster 2005).
} 
(40) SCOPE $\gg$ MORPHOLOGY (Desiderative and Associated Motion)

a. /ri'i-bú-si-nale/

stone-remove-MOT-DESID

'X wants to go along the road removing stones'

\begin{tabular}{|r|l|c|c|c|}
\hline & /ri'ibú, -si, -nale/ & SCOPE & $\mathrm{M}>\mathrm{D}$ & $\mathrm{D}>\mathrm{M}$ \\
\hline a. & ri'i-bú-si-nale & & & $*$ \\
\hline b. & ri'i-bú-na-simi & $* !$ & $*$ & \\
\hline
\end{tabular}

b. /isí-na-si/

urinate-DESID-MOT

' $\mathrm{X}$ is going along wanting to urinate'

\begin{tabular}{|r|l|c|c|c|}
\hline & /isí, -si, -na/ & SCOPE & M > D & D > M \\
\hline a. & isí-na-si & & $*$ & \\
\hline b. & isí-si-na & $* !$ & & $*$ \\
\hline
\end{tabular}

(41) SCOPE $\gg$ MORPHOLOGY (Causative and Associated Motion)

a. /počí-ti-si/

jump-CAUS-MOT

'X goes along making Y jump'

\begin{tabular}{|r|l|c|c|c|}
\hline & $/$ počí, -ti, -si/ & SCOPE & $\mathrm{C}>\mathrm{M}$ & $\mathrm{M}>\mathrm{C}$ \\
\hline a. & počí-ti-si & & & $*$ \\
\hline b. & počí-si-ti & $* !$ & $*$ & \\
\hline
\end{tabular}

b. /wikará-si-ti/

sing-MOT-CAUS

'X makes Y go along singing'

\begin{tabular}{|r|l|c|c|c|}
\hline & /wikará, -ti, -si/ & SCOPE & C > M & M > C \\
\hline a. & wikará-si-ti & & $*$ & \\
\hline b. & wikará-ti-si & $* !$ & & $*$ \\
\hline
\end{tabular}

Regardless of the ranking between the morphotactic constraints $\mathrm{M}>\mathrm{D}$ and $\mathrm{D}>\mathrm{M}$ or $\mathrm{C}>\mathrm{M}$ and $\mathrm{M}>\mathrm{C}$, the attested output will be determined by the satisfaction of the high ranked ScOPE constraint.

In the case of Desiderative and Evidential, on the other hand, I showed in Sect. 3.2 that it is the phonological subcategorization requirement of the Evidential which conditions the permutations of these suffixes. The subcategorization requirement of the evidential marker can be formalized in terms of Generalized Alignment (McCarthy and Prince 1993a, b; Yu 2007), where an edge of a morphological constituent coincides with the edge of a phonological pivot. ${ }^{16}$ This alignment constraint is defined in (42).

\footnotetext{
16 This alignment constraint is morphophonological in nature, and does not instantiate a $\mathrm{P} \gg \mathrm{M}$ ranking schema in OT (McCarthy and Prince 1993a, b). Crucially, this constraint does not imply any kind of optimization along a phonological scale, as would be predicted by this kind of model of the interaction between phonology and morphology.
} 
(42) Alignment of Evidential Construction

Align $\left([\mathrm{Ev}]_{\mathrm{Af}}, \mathrm{L}, \mathrm{Ft}\right.$ ', R): The left edge of the evidential marker is aligned to the right edge of the foot

This morphologically specific alignment constraint is ranked above Scope, as satisfaction of the Evidential construction's phonological subcategorization frame takes precedence over semantic compositionality. The ranking is justified in the tableaux in (43). The Desiderative-Evidential order is favored in tableau (43a) through SCOPE, as both candidates satisfy the optimal alignment of the Evidential. In tableau (43b), on the other hand, the winning candidate (candidate (a)) has an optimal alignment of the Evidential, and is selected despite violating Scope.

Alignment $\left(\mathrm{AlIGN}_{\mathrm{Ev}}\right)>>$ ScOPE

a. nakó-n-čane

/nakó-na-čane/

fist.fight-DESID-EV

'It sounds like they want to fist fight'

\begin{tabular}{|r|l|c|c|}
\hline & /nakó, -na, -čane/ & ALIGN $_{\mathrm{Ev}}$ & SCOPE \\
\hline a. & $(\text { nakó-n })_{\mathrm{Ft}}$-čane & & \\
\hline b. & $(\text { nakó })_{\mathrm{Ft}}-$ ča-nale & & $* !$ \\
\hline
\end{tabular}

b. atís-ča-nale

sneeze-EV-DESID

'It sounds like they want to sneeze'

\begin{tabular}{|r|l|c|c|}
\hline & /atísi, -na, -čane/ & ALIGN $_{\mathrm{Ev}}$ & SCOPE \\
\hline$\approx \mathrm{a}$. & $(\text { atís })_{\mathrm{Ft}}$-ča-nale & & $*$ \\
\hline b. & $(\text { atís })_{\mathrm{Ft}}$-na-čane & $* !$ & \\
\hline
\end{tabular}

So far we have the following constraint ranking: Align $\gg$ SCOPE $\gg$ Morphology. Scope is only overriden by phonological requirements specified in the subcategorization frame of the Evidential suffix. Morphotactic constraints in these cases do not play any role.

There are, however, interactions where ScOPE and Morphology must be inversely ranked in order to yield the correct results. This, for instance, is the case of Causative and Applicative. In (44), the ranking SCOPE $\gg \mathrm{C}>\mathrm{A}$ yields the attested suffix order pattern: a form with the compositionally-sound order Applicative-Causative will outrank a morphotactically stipulated sequence of Causative-Applicative.

\section{SCOPE $\gg$ MORPHOLOGY}

/mičí-ki-ti/

carve-APPL-CAUS

' $\mathrm{X}$ makes Y carve sticks for Y'

\begin{tabular}{|r|l|c|c|}
\hline & /mičí, -ti, -ki/ & SCOPE & C > A \\
\hline a. & mičí-ki-ti & & $*$ \\
\hline b. & mičí-ti-ki & $* !$ & \\
\hline
\end{tabular}


In (45), however, the opposite ranking $(\mathrm{C}>\mathrm{A} \gg \mathrm{SCOPE})$ is required to derive the winning candidate, which has the non-compositional Causative-Desiderative order.

MORPHOLOGY $\gg$ SCOPE
/o'pési-ti-ki/
vomit-CAUS-APPL
'X makes Y throw up on Z'
\begin{tabular}{|r|l|c|c|}
\hline & /o'pési, -ti, -ki/ & C > A & SCOPE \\
\hline a. & o'pési-ki-ti & $* !$ & \\
\hline b. & o'pési-ti-ki & & $*$ \\
\hline
\end{tabular}

Scope is also outranked by a morphotactic constraint $(C>D)$ in the cases of the non-compositional orderings of Causative and Desiderative exemplified in (33). There is no evidence that a constraint $\mathrm{D}>\mathrm{C}$ operates in the language, as the noncompositional orders of this pair of suffixes exclusively involve the sequence Causative-Desiderative. A sample derivation is exemplified in tableau (46).

$$
\text { MORPHOLOGY 》SCOPE (V-CAUS-DESID) }
$$

a. /rosowá-ri-ti-nale/ cough-CAUS-CAUS-DESID 'X makes Y want to cough'

\begin{tabular}{|r|l|c|c|}
\hline & /rosowár, -ti, -nale/ & $\mathrm{C}>\mathrm{D}$ & SCOPE \\
\hline a. & rosowári-na-ti & $* !$ & \\
\hline b. & rosowári-ti-nale & & $*$ \\
\hline
\end{tabular}

This ranking is reverted in the cases where the Desiderative-Causative order happens to be compositional (see (22) above). This is exemplified in tableau (47).

SCOPE $\gg$ MORPHOLOGY (Causative and Desiderative)
/bahí-na-ti/
drink-DESID-CAUS
'X makes Y want to drink water'
\begin{tabular}{|r|l|c|c|}
\hline & /bahí, -ti, -na/ & SCOPE & C > D \\
\hline a. & bahí-ti-na & $* !$ & \\
\hline b. & bahí-na-ti & & $*$ \\
\hline
\end{tabular}

Finally, we have seen that Causative and Associated Motion and Desiderative and Associated Motion are attested in variable orders, where the variation in placement does not correspond to scope (see (34-35) above). In these cases we must also posit that SCOPE is outranked by morphotactic constraints. Furthermore, morphotactic constraints that specify each attested suffix sequence must be freely ranked with respect to each other in order to obtain the correct results. This is 
exemplified in tableaux (48) and (49), with the ranking and evaluation for noncompositional Causative-Motion and Motion-Causative, respectively.

$$
\text { MORPHOLOGY } \gg \operatorname{SCOPE}(\mathbf{C}>\mathbf{M} \gg \mathbf{M}>\mathbf{C} \gg \text { Scope })
$$

a. /piwá-ri-si/ smoke-CAUS-MOT

' $\mathrm{X}$ makes Y go along smoking'

\begin{tabular}{|r|l|c|c|c|}
\hline & /piwá, -ri, -si/ & $\mathrm{C}>\mathrm{M}$ & $\mathrm{M}>\mathrm{C}$ & SCOPE \\
\hline a. & piwá-si-ri & $* !$ & & \\
\hline b. & piwá-ri-si & & $*$ & $*$ \\
\hline
\end{tabular}

MORPHOLOGY $\gg$ SCOPE $(\mathbf{M}>\mathbf{C} \gg \mathbf{C}>\mathbf{M} \gg$ Scope $)$
/sú-si-ti/
sew-MOT-CAUS
'X goes along making Y sew'
\begin{tabular}{|r|l|c|c|c|}
\hline & /sú, -ti, -si/ & $\mathrm{M}>\mathrm{C}$ & $\mathrm{C}>\mathrm{M}$ & SCOPE \\
\hline a. & sú-ti-si & $* !$ & & \\
\hline$\sigma$ b. & sú-si-ti & & $*$ & $*$ \\
\hline
\end{tabular}

We have, then, that there are two coexisting constraint rankings operating in Choguita Rarámuri: Align $\gg$ Scope $\gg$ Morphology and Align $\gg$ Morphology $\gg$ SCOPE, where scope and morphotactic constraints are freely ordered, and always outranked by phonology through phonological subcategorization. Furthermore, morphotactic constraints are freely ranked as well, modeling the cases in which variable suffix order is not semantically nor phonologically motivated. ${ }^{17}$

If we are correct assuming that in this system scope and morphotactic constraints are freely ranked, then this carries a typological implication: systems where semantically motivated constraints interact with morphotactically stipulated constraints (which include mixed scope/template systems (as defined in Hyman 2003) have been alternatively analyzed as systems where morphotactic constraints are

\footnotetext{
${ }^{17}$ It is of course always possible to resort to an analysis in which morphotactic constraints are always overarching and scope only emergent (i.e., where MoRPhology and Scope are never re-ranked). Two rankings would be necessary in such an analysis. First, forms in which morpheme order reflects scope would be modeled with a ranking where higher-ranked morphotactic constraints would not be critically ranked with respect to each other, leaving scope an emergent role:
}

i) /ri'i-bú-si-nale/ stone-remove-MOT-DESID

'X wants to go along the road removing stones'

\begin{tabular}{|r|l|c:c|c|}
\hline & /ri'ibú, -si, -nale/ & $\mathrm{M}>\mathrm{D}$ & $\mathrm{D}>\mathrm{M}$ & SCOPE \\
\hline a. & ri'i-bú-si-nale & & $*$ & \\
\hline b. & ri'i-bú-na-simi & $*$ & & $* !$ \\
\hline
\end{tabular}


always emergent or systems where scope may be outranked by morphotactic constraints. ${ }^{18}$ The Choguita Rarámuri system would thus instantiate a new type of system, in which the relationship between these two driving forces of affix order is better characterized as one of variable ranking. Next, I present data that point at both grammar-internal and grammar-external sources of this particular tension between scope and morphotactic constraints in Choguita Rarámuri.

\section{Sources of morphotactically stipulated suffix sequences}

While Choguita Rarámuri morphology cannot be characterized as position-class (Sect. 2), I have shown that in this language morphotactic constraints operate in a defined area of the structure of the verb (recall that variable affix ordering, whether determined by scope, phonological subcategorization or neither, is restricted to two verbal domains, the Syntactic and the Aspectual Stem levels (7)). In the proposed analysis, I have resorted to free ranking between morphotactic constraints to model the set of unconstrained pair-wise permutations attested in this language. But while a useful descriptive device, we might want to ask if these morphotactic statements bear any relation with other components of Choguita Rarámuri's grammar. In the case of the Bantu relative-order template system, it has been proposed that the templatic restrictions on suffix order are linked to morphophonological conditions on the verb stem (Hyman 2003; Good 2006). In the case of Chintang free prefix order, it has been suggested that variability of prefix placement is linked to priming and social-model copying (Bickel et al. 2007, p. 65). In the next subsection, I report

\section{Footnote 17 continued}

A second ranking would be necessary to account for variable, non-compositional suffix sequences. The higher ranked morphotactic constraints would be freely ranked:

ii)

a. /nará-si-nale/

cry-MOT-DESID

'X goes along wanting to cry'

\begin{tabular}{|r|l|c|c|c|}
\hline & /nará, -si, -nale/ & $\mathrm{M}>\mathrm{D}$ & $\mathrm{D}>\mathrm{M}$ & SCOPE \\
\hline a. & nará-si-nale & & $*$ & $*$ \\
\hline b. & nará-na-simi & $* !$ & & \\
\hline
\end{tabular}

b. /koči-nále-si/

sleep-DESID-MOT

'X wants to go along sleeping'

\begin{tabular}{|r|l|c|c|c|}
\hline & /koči, -si, -nale/ & $\mathrm{D}>\mathrm{M}$ & $\mathrm{M}>\mathrm{D}$ & SCOPE \\
\hline a. & koči-nále-si & & $*$ & $*$ \\
\hline b. & koči-si-nale & $* !$ & & \\
\hline
\end{tabular}

However, this analysis misses the generalizations captured by the proposed analysis, where most cases of fixed suffix order reflect fixed scope and where scope, in effect, outranks the morphotactic constraints in a fair amount of cases.

18 Though Hyman's (2003) analysis of Chichewa also involves different rankings between morphotactic constraints and "mirror" (scopal) constraints, he states that cases where morpheme order reflects semantic compositionality stem from "'exceptional' overrides" (2003, p. 2); a Pan-Bantu default template is responsible for determining the attested suffix order patterns of Chichewa. 
on two phenomena that hint at both the grammar-external and grammar-internal conditions at play in conditioning variable affix ordering in Choguita Rarámuri that is not scopal or phonologically motivated.

\subsection{Suffix sequences through priming}

Some suffix orderings in this language seem to be at least partially generated through priming effects. It is often the case that during elicitation of morphologically complex constructions, a particular morpheme sequence will become fixed and serve as the base for further suffixation when derived, more complex forms are elicited, regardless of the intended semantic interpretation. ${ }^{19}$ Consider for instance the transcribed sequence in (50), where the speaker produces a form with a semantically compositional order Causative-Motion ([X goes along [making $\mathrm{Y}$ jump] ]) in the first answer (50b), and uses the same morpheme order to express the opposite scopal relationship in the next answer ([X makes [y go along V] ]) (50d).

(50) Priming of Causative-Motion order [SFH 07 2:38/el]

a. GC: čú regá aniwá: "me vas a ir haciéndome que brinque?"

'How do you say "will you go along making me jump"?

\section{Compositional CAUS-MOT}

b. SF: muhé á tamí čipó-r-si-ma?

/muhé á tamí čipó-ri-si-ma/

2sG.NOM AFF 1sG.ACC jump-CAUS-MOT-FUT.SG

[X goes along [making Y jump] ]

c. GC: a'rí: "te voy a hacer que le vayas pidiendo dinero"?

"And: "I'll make you go along asking her for money"?

Non-compositional caus-MOT

$\begin{array}{lllllll}\text { d. SF: } & \text { ne } & \text { ko } & \text { á } & \text { mi } & \text { tá-r-si-ma } & \text { winomí } \\ & \text { /ne } & \text { ko } & \text { á } & \text { mi } & \text { tá-ri-si-ma } & \text { wenomí/ } \\ & \text { 1sG.NOM } & \text { EMPH } & \text { AFF } & \text { 2SG.ACC } & \text { ask-CAUS-MOT-FUT.SG } & \text { money } \\ & \text { [X makes } & \text { [Y go along asking] ] } & & \end{array}$

In the transcribed sequence in (51) with a different speaker, the first elicited response involves a causative stem (rará-ri-ma 'buy-CAUS-FUT.SG' in (51b)). This same causative stem is used in the second response, in which a different inflectional marker is elicited (rará-r-si 'buy-CAUS-IMP.PL' in (51d)). In a third response, the translation for the Spanish stimulus is a causative built of an applicative stem of the same root (rarí-r-si 'buy.APPL-CAUS-IMP.PL' in (51f)). Finally, the speaker produces a form where the same causative stem is used, followed by the Desiderative suffix (rarí-r-niri-si 'buy-CAUS-DESID-IMP.PL' in (51h)). Crucially, this form features a

\footnotetext{
${ }^{19}$ I would like to point out that, as with non-compositional, morphotactically stipulated suffix orders, these effects are present within and across individual speakers.
} 
non-compositional order between Causative and Desiderative. ${ }^{20}$ Discussion of the form produced made it clear that the intended meaning was one where an agent makes the causee feel the desire to buy something.

(51) Priming of Causative-Desiderative order [BFL 06 2:134/el]

a. GC: ču riká aniwá "te voy a hacer que compres zapatos"? 'How do you say "I'll make you buy shoes"?

b. BF: mi=ni sapáto rará-ri-ma orá /mi=ni sapáto rará-ri-ma olá/

2sG.ACC $=1$ sG.NOM shoes buy-CAUS-FUT.SG CER

c. GC: a'rí ču riká aniwá "te hice comprar zapatos"?

'And how do you say "I made you buy shoes"?'

d. BF: $\quad m i=n i$ sapáto rará-r-ki

Root-CaUS

$/ \mathrm{mi}=\mathrm{ni}$

sapáto rará-ri-ki/

2SG.ACC $=1$ SG.NOM shoes buy-CAUS-PST.1

e. GC: a'rí, "háganlos comprar frijol!"?

'And "make them buy beans!"?'

f. BF: muní rarí-r-si

/muní rarí-ri-si/

beans buy.APPL-CAUS-IMP.PL

g. GC: y cómo sería "háganlos querer comprar soda" ...como antojándolos?

"And how would you say "make them want to buy soda"

...like if you would tease them?'

Non-compositional CAUS-DESID order:

h. BF: rarí-r-niri-si

Root-CAUS-DESID

/rarí-ri-nale-si/

buY-CAUS-DESID-IMP.PL

[X makes [Y want to buy soda] ]

The non-compositional order of Causative and Associated Motion in (50d) and the non-compositional order of Causative and Desiderative in (51h) exemplify a general pattern where morphologically complex constructions contain semantically non-compositional suffix sequences that mirror sequences previously produced. ${ }^{21}$

There are probably more factors involved in conditioning non-compositional suffix sequences in Choguita Rarámuri in addition to priming effects. The nature of any of these factors and their interaction could only be sorted out through a largecorpus study, which is at present still not available for this language. It is clear, however, that while the semantics in the reported cases is unambiguous, morpheme

\footnotetext{
${ }^{20}$ As the editors point out, the non-compositional order of Causative-Motion in (50) and of CausativeDesiderative in (51) match the proposed structure in (4).

${ }^{21}$ In addition, the form rarí-r-niri-si in (50h) is composed of a root with an $i$-vocalism, an alternative root form that is only available to a subset of verbal roots in Choguita Rarámuri with final unspecified vowels. These types of roots can either have a final- $a$ (e.g., rará as in (50b,d,f)), or a final-i allomorph (e.g., rarí, as in the form provided in the last answer). Choice of stem form is subject to inter-speaker variation, and, as this example suggests, can also be affected by priming effects.
} 
order did not reflect the actual semantic composition of the inflected verb, even though these same speakers produce morphologically complex forms with fully compositional semantics.

\subsection{Multiple exponence}

Finally, there is another phenomenon in this Uto-Aztecan language that conditions semantically non-compositional suffix sequences, namely Multiple (or extended) Exponence (ME), a one-to-many mapping between a (morphological) category and its formal expression (Matthews 1974). There are four patterns of ME in Choguita Rarámuri, one of which involves the Causative suffix. In (52), a causer argument is introduced to the basic predicate through a Causative suffix (-ri) (52a)); this causative stem may in turn be further causativized, introducing a second causer argument (52b).

(52) Recursive application of causative suffixes
a. ne mi biné-ri-ma wikará
1sSG.NOM 2sG.ACC learn-CAUS-FUT.SG sing
'I will teach (lit. make you learn) how to sing'
'Voy a hacerte que aprendas cómo cantar'
[ [learn] + CAUs $=$ teach $]$
b. nihé mi biné-r-ti-ki kúruwi
1SG.NOM 2SG.ACC learn-CAUS-CAUS-PST.1 children
'I made you make the children learn
(lit. I made you teach to the children)'
'Hice que tú les enseñaras a los niños'
$[$ [ [learn $]+$ CAUs $=$ teach $]+$ CAUS $=$ make teach $]$

While each causative marker in (52) matches a causative operation, it is also very common to find cases where forms with one causative marker (53a) are semantically equivalent to (and stand in free variation with) forms with two causative markers (53b). Notice that the semantically recursive causatives in (52b) and the redundantly marked causatives in (53b) are expressed through the same sequence of allomorphs $(-r-t i-)$.

(53) Causative doubling with no recursive semantics
a. ne $=$ mi ra'ičá-ri-ma
1sG.NOM=2SG.ACC speak-CAUS-FUT.SG
'I will make you speak'
'Te voy a hacer que hables'
*'I will make you make him speak'
[06 2:163/el]
$[$ speak $]+$ CAUs $=$ make speak $]$
b. á birá tamí ra'ičá-r-ti-ri siríame
AFF really 1sG.ACC speak-CAUS-CAUS-PST governor
'The governor made me speak'


'El gobernador me hizo hablar'

*'I will make you make him speak'

[06 2:163/el]

$[$ speak $]+$ CAUs $=$ make speak $]$

The successive causative morphemes in (52b) match two successive causative operations ([cause [teach = cause (learn)] ]), but in (53b) the recursivity of these affixes does not match a parallel recursive causative operation, thus challenging the Mirror Principle's proposal that morphological expressions are isomorphic with syntactic or semantic operations.

This mismatch between meaning and form is prosodically conditioned: finalstress stems optionally display ME (54a), but ME is never attested with forms where the base for affixation has pre-final stress (54b).

a. Causative doubling with final stress stems

$\begin{array}{lll}\text { One causative } & \text { Two causatives } & \text { Gloss } \\ \text { mé-r-ma } & \text { mé-r-ti-ma } & \text { 'win-CAUS(-CAUS)-FUT.SG' } \\ \text { ko'í-ri-ri } & \text { ko'í-r-ti-ma } & \text { 'kill.pl-CAUS(-CAUS)-FUT.SG' } \\ \text { sirú-ri-ri } & \text { sirú-r-t-i } & \text { 'hunt-CAUS(-CAUS)-IMPF' } \\ \text { bahí-ri-a } & \text { bahí-r-ti-po } & \text { 'drink-CAUS(-CAUS)-FUT.PASs' } \\ \text { aka-rá-ri-ma } & \text { aka-rá-r-ti-ma } & \text { 'sandal-FACT-CAUS(-CAUS)-FUT.SG' }\end{array}$

b. No causative doubling with prefinal stress stems

$\begin{array}{lll}\text { ték-ti-ma } & \text { *ték-r-ti-ma } & \text { 'be.drunk.PL-CAUS(-CAUS)FUT.SG' } \\ \text { paník-ti-ma } & \text { *paník-r-ti-ma } & \text { 'wash.hands-CAUS(-CAUS)-FUT.SG' } \\ \text { opéč-ti-ma } & \text { *opéč-r-ti-ma } & \text { 'vomit-CAUS(-CAUS)-FUT.SG' } \\ \text { bačím-ti-po } & \text { *bačím-r-ti-po } & \text { 'sprinkle-CAUS(-CAUS)-FUT.PL' } \\ \text { očóp-ti-po } & \text { *očóp-r-ti-po } & \text { 'stick-CAUS(-CAUS)-FUT.PL' }\end{array}$

I have proposed (Caballero 2008; to appear a, b) that the synchronic motivation of ME in Choguita Rarámuri is structural well-formedness: general morphophonological properties (such as stress induced post-tonic deletion in (53b)) make the inner exponents structurally defective (less susceptible to morphological segmentation), enforcing a well-formedness requirement at a subconstituent level (a 'slot' in the word) (cf. Inkelas and Zoll (2005) analysis of empty morphemes). The structurally defective stem is thus repaired through the addition of a second exponent which is aligned with a syllable rhyme (e.g., mé-r.-ti.-ma 'win-CAus-CAusFUT.SG', si.rú-r.-ti.-ma 'hunt-CAUS-CAUS-FUT.SG', etc.).

This pattern of prosodically-driven mismatch between form and meaning also yields suffix sequences that are independent of compositionality. Consider, for instance, the examples in (55), where compositional orders are underlined, and noncompositional orders are highlighted with italics. In these cases, an inner sequence of Applicative followed by the Causative suffix $-t i$ is compositional, but the sequence composed of Causative suffix $-t i$ and a subsequent Applicative suffix $-k i$ is not. 
(55) ME and non-compositional suffix order

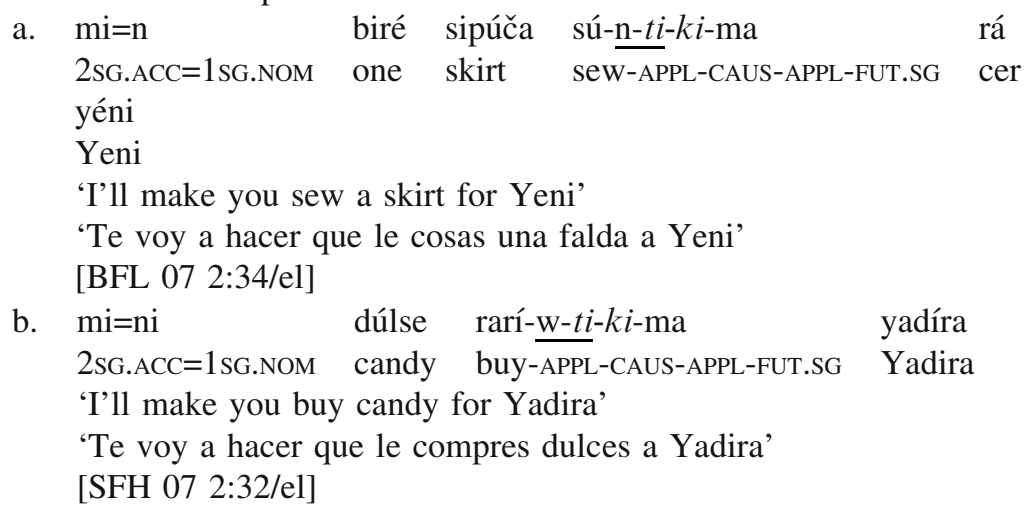

In (55), an inner Applicative exponent undergoes post-tonic syncope, requiring a second Applicative exponent to be aligned with a syllable rhyme. As we have seen in Sect. 3.2.3, the order of the Causative $-t i$ suffix and the Applicative $-k i$ suffix does not reflect semantic scope. The second Applicative morpheme, whose exponence is morphophonologically conditioned, is ordered after an intervening Causative suffix, thus generating a non-compositional Causative-Applicative sequence.

These cases suggest that the factor that drives ME can concomitantly produce suffix orderings which are independent of semantic compositionality. Semantically vacuous suffix doubling and (at least some cases of) variable suffix permutation originate in the morphophonology, not the morphosyntax.

\section{Conclusion and questions for further research}

In this paper, I have documented Choguita Rarámuri suffix order patterns and showed how most ordering restrictions in this language follow from scope, where the relative order of exponents is correlated with their semantic compositionality. Thus, as predicted by Rice's Scope Hypothesis, morphemes with fixed scope occur in a fixed linear order, and morphemes where scope can be reversed occur in variable order, with interpretation related to order (2000, p. 79). I have also shown that there are two exceptions to these generalizations. First, there is variable ordering of suffixes that have a fixed scopal relationship, which is driven by phonological subcategorization. And second, there are suffix permutations that cannot be reduced to any general grammatical principle. Crucially, I have shown how these unmotivated permutations also occur with suffixes where scope-related variable order is also attested. The interaction between phonological subcategorization, scope and morphotactic constraints was analyzed through free ranking between scope and morphotactic constraints, with overarching phonological subcategorization, formalized through morpho-prosodic alignment. I have discussed how the proposed analysis of Choguita Rarámuri suffix order expands the typology of affix order systems which mix scopal restrictions and morphologically specified prece- 
dence relations (including mixed scope/template systems) by presenting a system where scope and morphotactic constraints are variably ranked. Furthermore, I have suggested that these morphologically stipulated restrictions are descriptive devices with possible sources in priming and morphophonological conditions on stems, two phenomena that have been previously documented as influencing variability in prefix placement (Bickel et al. 2007) and fixed templatic suffix order (Hyman 2003; Good 2006), respectively.

Finally, this paper has documented a new case of free affix ordering, a type of affix order system that has been sparsely documented to date (Stump 2006; Bickel et al. 2007). To the best of my knowledge, unconstrained affix permutations have only been documented in Kiranti (Sino-Tibetan; Bickel et al. 2007) and Totonacan languages (McFarland 2006; Beck 2007). Other cases of less unconstrained types of free affix permutations have been reported in Quechua (Quechuan; Muysken 1988), Mari (Uralic; Luutonen 1997), Chichewa (Bantu; Hyman 2003), and Pulaar (Atlantic; Paster 2005). ${ }^{22}$ There are still not enough cases for a typology of free affix order systems to be viable, and it is worth asking if the apparent rarity of these cases is an artifact of field methodologies that overlook variation. We might also ask if there are any typological implications of this kind of system, i.e. how agglutinatingspecific is this phenomenon? As documentation of endangered and less studied languages grows, potentially bringing new cases of free affix permutation to light, we might be able to start answering these questions.

Acknowledgements I would like to thank Andrew Garrett, Larry Hyman, Sharon Inkelas, Johanna Nichols, Lynn Nichols, Nicholas Fleisher, Teresa McFarland and the audiences at the Workshop on Affix Ordering at the $13^{\text {th }}$ International Morphology Meeting in Vienna, the Berkeley Phonetics and Phonology Forum, the Linguistics Department colloquium at the University of California, San Diego and the Linguistics Department colloquium at Rice University for valuable comments and suggestions. I am extremely grateful to my Rarámuri colleagues and teachers, especially Sebastián Fuentes Holguín, Bertha Fuentes Loya and Luz Elena León Ramírez for their patience and insights about their language. I am also grateful to two anonymous reviewers and the editors for detailed comments and criticisms. All remaining errors and omissions are my sole responsibility. This study was made possible by fellowships by Mexico's Science and Technology Council (Consejo Nacional de Ciencia y Tecnología (CONACYT)), The University of California Institute for Mexico and the United States (UCMEXUS) and the Endangered Languages Documentation Programme (ELDP) of the Hans Rausing Endangered Languages Project.

Open Access This article is distributed under the terms of the Creative Commons Attribution Noncommercial License which permits any noncommercial use, distribution, and reproduction in any medium, provided the original author(s) and source are credited.

\section{References}

Alsina, A. (1999). Where's the mirror principle? The Linguistic Review, 16(1), 1-42.

Anttila, A. (1995). Deriving variation from grammar: A study of Finnish genitives. Ms., Stanford University.

Baker, M. (1985). The mirror principle and morphosyntactic explanation. Linguistic Inquiry, 16, 373-416.

\footnotetext{
22 Additional cases of variable affix order are also reported in better known languages, such as Bulgarian (Manova this volume) and English (Zirkel this volume; Plag and Baayen 2009).
} 
Beck, D. (2007). Variable ordering of affixes in Upper Necaxa Totonac. In Workshop on structure and constituency of the languages of the americas 12. Vancouver: UBC Working Papers in Linguistics.

Bickel, B., Banjade, G., Gaenszle, M., Lieven, E., Paudyal, N., Purna Rai, I., et al. (2007). Free prefix ordering in Chintang. Language, 83, 1-31.

Booij, G. (2002). Prosodic restrictions on affixation in Dutch. In G. Booij \& J. van Marle (Eds.), Yearbook of morphology 2001 (pp. 183-202). Dordrecht: Kluwer.

Bybee, J. (1985). Morphology: A study of the relation between meaning and form. Amsterdam: Benjamins.

Caballero, G. (2008). Choguita Rarámuri (Tarahumara) phonology and morphology. Doctoral dissertation, University of California, Berkeley.

Caballero, G. (to appear a). Multiple exponence of derivational morphology in Rarámuri (Tarahumara). Proceedings of the Berkeley Linguistics Society, 33.

Caballero, G. (to appear b). Multiple exponence and the phonology-morphology interface. Proceedings of the North East Linguistics Society, 39.

Condoravdi, C., \& Kiparsky, P. (1998). Optimal order and scope. Paper presented at Lexicon in Focus, Heinrich-Heine. Universität Dusseldorf.

Greenberg, J. (1963). Some universals of grammar with particulare reference to the order of meaningful elements. In. J. Greenberg (Ed.), Universals of language. Cambridge: MIT Press.

Good, J. (2003). Strong linearity: Three case studies towards a theory of morphosyntactic templatic constructions. Doctoral dissertation, University of California, Berkeley.

Good, J. (2006). Constraining morphosyntactic templates: A case study of Bantu verbal suffixes. Paper presented at the 2006 Linguistic Society of America Annual Meeting. Albuquerque, NM.

Guy, G. (1997). Competence, performance, and the generative grammar of variation. In F. Hinskens, R. Van Hout, \& W.L. Wetzels (Eds.), Variation, change, and phonological theory (pp. 125-143). Amsterdam: John Benjamins.

Hargus, S., \& Tuttle, S. G. (1997). Augmentation as affixation in Athabaskan languages. Phonology, 14, $177-220$.

Hyman, L. (1993). Conceptual issues in the comparative study of the Bantu verb stem. In S. S. Mufwene \& L. Moshi (Eds.), Topics in African linguistics (pp. 3-34). Amsterdam: Benjamins.

Hyman, L., (2003). Suffix ordering in Bantu: A morphocentric approach. In Yearbook of morphology 2002 (pp. 245-281). Dordrecht: Kluwer.

Hyman, L., \& Mchombo, S. (1992). Morphotactic constraints in the Chichewa verb stem. Berkeley Linguistic Society, 18, 350-364.

Inkelas, S. (1990). Prosodic constituency in the lexicon. New York: Garland.

Inkelas, S. (1993). Nimboran position class morphology. Natural Language and Linguistic Theory, 11, 559-624.

Inkelas, S. \& Zoll, C. (2005) Reduplication: Doubling in morphology. Cambridge: Cambridge University Press.

Itô, J., \& Mester, A. (1997). Correspondence and compositionality: The Gagyo variation in Japanese phonology. In I. Roca (Ed.), Derivations and constraints in phonology (pp. 419-462). Oxford: Clarendon Press.

Kager, R. (1999). Optimality theory. Cambridge: Cambridge University Press.

Kiparsky, P. (1982). Explanation in phonology. Dordrecht: Foris.

Kiparsky, P. (1993). Variable rules. In Handout distributed at the Rutgers Optimality Workshop (ROW1).

Lieber, R. (1980). On the organization of the lexicon. Doctoral dissertation, MIT.

Luutonen, J. (1997). The variation of morpheme order in Mari declension. Helsinki: SuomalaisUgrilainen Seura.

Manova, S. (2010). Suffix combinations in Bulgarian: Parsability and hierarchy-based ordering. Morphology, 20. doi:10.1007/s11525-010-9148-3.

Matthews, P. (1974). Morphology. Cambridge: Cambridge University Press.

McCarthy, J., \& Prince, A. (1993a). Prosodic morphology I: Constraint interaction and satisfaction. Ms., University of Massachusetts, Amherst and Rutgers University.

McCarthy, J., \& Prince, A. (1993b). Generalized Alignment. In G. Booij \& J. van Marle, (Eds.), Yearbook of morphology 1993 (pp. 79-153). Dordrecht: Kluwer.

McFarland, T. (2006). Variable affix ordering in Totonaco de Filomeno Mata. Ms., University of California, Berkeley.

Muysken, P. (1988). Affix order and interpretation: Quechua. In M. Evaraert, A. Evers, R. Huybregts, \& M. Trommelen (Eds.), Morphology and modularity (pp. 259-279). Dordrecht: Foris. 
Paster, M. (2005). Pulaar verbal extensions and phonologically driven affix order. In G. Booij \& J. van Marle (Eds.), Yearbook of morphology 2005 (pp. 155-199). Dordrecht: Springer.

Paster, M. (2006a). Phonological conditions on affixation. Doctoral dissertation, University of California, Berkeley.

Paster, M. (2006b). A survey of phonological affix order with special attention to Pulaar. In L. Baterman \& C. Ussery (Eds.), Proceedings of the 35th Annual meeting of the North Eastern Linguistics Society. Amherst, MA: GLSA Publications.

Plag, I., \& Baayen, R.H. 2009. Suffix ordering and morphological processing. Language, 85, 106-149.

Plank, F. (1999). Split morphology: How agglutination and flexion mix. In Linguistic Typology, 3.3, 279-340.

Prince, A., \& Smolensky, P. (1993). Optimality theory: Constraint interaction in generative grammar (unpublished manuscript), Rutgers University and the University of Boulder, Colorado.

Reynolds, W. (1994). Variation and phonological theory. Doctoral dissertation, University of Pennsylvania.

Rice, K. (2000). Morpheme order and semantic scope. Cambridge: Cambridge University Press.

Selkirk, E. (1982). The syntax of words. Cambridge: MIT Press.

Simpson, J., \& Withgott, M. (1986). Pronominal clitic clusters and templates. In H. Borer (Ed.), Syntax and semantics 19: The syntax of pronominal clitics (pp. 149-174). New York: Academic.

Stump, G. (1992). Position classes and morphological theory. In G. Booij \& J. van Marle (Eds.), Yearbook of Morphology 1992 (pp. 129-180). Dordrecht: Kluwer.

Stump, G. (2006). Template morphology. In K. Brown (Ed.), Encyclopedia of language and linguistics Vol. 12, pp. 559-563. Oxford: Elsevier.

$\mathrm{Yu}$, A. (2003). The morphology and phonology of infixation. Doctoral Dissertation, University of California, Berkeley.

Yu, A. (2007). A natural history of infixation. Oxford: Oxford University Press.

Zirkel, L. (2010). Prefix combinations in English: Structural and processing factors. Morphology, 20. doi:10.1007/s11525-010-9151-8. 